\title{
RESIDUES OF NEONICOTINOID INSECTICIDES IN BEE COLLECTED PLANT MATERIALS FROM OILSEED RAPE CROPS AND THEIR EFFECT ON BEE COLONIES
}

\author{
Krystyna Pohorecka ${ }^{1}$, Piotr Skubida ${ }^{2}$, Artur Miszczak ${ }^{3}$, \\ Piotr Semkiw ${ }^{2}$, Piotr Sikorski ${ }^{3}$ Katarzyna Zagibajło ${ }^{3}$,

$\mathrm{S} \mathrm{u} \mathrm{m} \mathrm{m} \mathrm{a} \mathrm{r} \mathrm{y}$

The risk exposure of bee colonies to the toxicity of systemic neonicotinoid insecticides was assessed. Various methods of chemical prevention of commercial winter and spring oilseed rape crops in field-realistic conditions were taken into account in the assessment. Pesticides were applied in accordance with the actual agricultural practice. Commercial crop protection products with thiamethoxam, clothianidin or imidacloprid were used as seed treatment. Formulations containing acetamiprid or thiacloprid were used for spraying. Fifteen healthy bee colonies were placed in close proximity to each of the oilseed rape fields throughout the blooming period. During florescence, the samples of nectar (directly from flowers and nectar flow from combs) and pollen loads were collected repeatedly. Samples of honey, bee bread and adult bees were taken one week after the end of plants flowering. To ensure high specificity and sensitivity of analysed pestcicides modified QuEChERS extraction method and liquid chromatography coupled with tandem mass spectrometry (LC-MS/MS) was used. The five of neonicotinoid insecticides (imidacloprid, clothianidin, thiametoxam, acetamiprid and thiacloprid) were analyzed in multi-residue method with $0.1-10 \mathrm{ng} / \mathrm{g}$ limits of detection. Palynological analysis was done to determine the botanical origin of the nectar, honey and pollen. Development of bee colonies (brood area, worker biomass, colony health) was assessed every 3 weeks until the end of the beekeeping season. The amount of pollen collected by bees per hive, bee bread area and rape honey yield was also measured. The long-term effects of insecticides on bees were estimated using the same methods in April of the following year.

All the neonicotinoid insecticides applied to control oilseed rape pests were present in the samples of nectar and pollen. Their residue levels were lower than the acute oral and contact $\mathrm{LD}_{50}$ values. Among five examined neonicotinoids, the most frequently detected were: thiamethoxam, thiacloprid and acetamiprid. These substances were present in 65,64 , and $51 \%$ of the nectar samples and in 37,62 , and $45 \%$ of the pollen samples, respectively. The highest level of residues were noted after the thiamethoxam seed treatment; on average, 4.2 and $3.8 \mathrm{ng} / \mathrm{g}$ in the nectar and pollen samples. In the nectar and pollen samples from winter rape fields, lower levels of neonicotinoid residues were found in comparison to spring rape samples. The contaminations of neonicotinoids applied as seed dressing in nectar samples were significantly higher in comparison to the pollen 
samples. No negative effects of neonicotinoids on the bee mortality, brood development, strength, and honey yield of healthy bee colonies were found throughout the study period. However, the risk exposure of bee colonies on adverse impact of pesticide residues is high in areas of intensively cultivated oilseed rape.

Keywords: honey bees, oilseed rape, neonicotinoid insecticides, seed-treatment, spraying, residue analysis, short- and long-term assessment.

\section{INTRODUCTION}

Out of all of the crops in Poland, oilseed rape (Brassica napus) is the most important and abundant forage source for honeybees. It is planted over an area of 950,000 hectares. Those cultivars planted are mainly winter cultivars (sowing in August, flowering at the turn of April and May). Cultivation of spring oilseed rape (about 120,000 ha of crops) is not very common because of the Polish climate. Spring oilseed rape is sown at the turn of March and April and begins to bloom at the end of June. The mean yield of oilseed rape honey from one colony may be up to $27 \mathrm{~kg}$ (Kołtowski, 2007). However, pesticides (insecticides, herbicides, fungicides) are extensively used as seed dressings and as sprays for protection of oilseed rape crops. The use of these pesticides may have contributed to the loss of pollinators (Johnson et al., 2010). The neonicotinoid insecticides, which include imidacloprid, acetamiprid, clothianidin, thiamethoxam, and thiacloprid are a new class of systemic insecticides, widely used in the agricultural practice. The neonicotinoid insecticide compounds are transported via the plant sap to different plant parts (Schmuck et al., 2001; Cutler and Scott-Dupree, 2007; Girolami et al., 2009; Tapparo et al., 2011). As a consequence, the bees could be exposed over long periods of time to the insecticide residue in the nectar and pollen which the bees collect. The adverse effects (lethal and sublethal) of neonicotinoids on bees have been described in laboratory studies (Decourtye et al., 2001; 2004a,b; 2005; 2007; Bortolotti et al., 2003; Iwasa et al., 2004; Desneux et al., 2007; Thompson and Maus, 2007; Yang et al., 2008; Aliouane et al., 2009; Laurino et al., 2011; Schneider et al.,
2012). Yet, there is still not enough data available about the toxic effect of residues on bee colonies after the application of systemic insecticides in field-realistic dosages.

The first purpose of our study was to measure the concentration of neonicotinoid insecticides (thiamethoxam, clothianidin, imidacloprid acetamiprid, and thiacloprid) in plant materials (nectar, pollen), and bee products (honey, bee bread). The measured insecticides refer to those which had been applied in field-realistic dosages to control oilseed rape pests. The second purpose was to assess the short- and long-term effect of these contaminants on bee colonies.

\section{MATERIALS AND METHODS}

\section{Oilseed rape crops}

The field studies were conducted in collaboration with the Department of Experimental Agriculture Institute of Soil Science and Plant Cultivation. A different method of chemical protection was used on each crop. Pesticides were applied in accordance with the actual agricultural practice (formulations authorised in Poland). In 2010, two winter oilseed rape fields (with an area of 41 ha - field A, and 35 ha - field B) were treated with thiamethoxam (CRUISER OSR 322 FS) and imidacloprid (CHINOOK PLUS $500 \mathrm{FS})$ as seed dressing, respectively. The acetamiprid (MOSPILAN 20 SP) and thiacloprid (PROTEUS 110 OD) were used as a foliar spray.

In 2012, on three separate spring oilseed rape fields the thiamethoxam (CRUISER OSR $322 \mathrm{FS}$ ), clothianidin (MODESTO $480 \mathrm{FS}$ ), and imidacloprid (CHINOOK PLUS 500 FS) were applied for seed treatment. The plants were sprayed with thiacloprid (PROTEUS 110 OD). The areas under cultivation of oilseed rape were 
of 29 ha (field C), 21 ha (field D), 17 ha (field E), respectively. All the crops were also treated with herbicides, fungicides and insecticides from other chemical classes. The detailed description of the plant protection is shown in Table 1. The blooming period of winter oilseed rape was from the $31^{\text {st }}$ of April to the $21^{\text {st }}$ of May 2010. The spring oilseed rape flourished from the $14^{\text {th }}$ of June to the $2^{\text {nd }}$ of July 2012.

\section{Bee colonies}

The studies were performed on bee colonies (Apis mellifera carnica, Apis mellifera caucasica) kept in Wielkopolski hives (frame size $360 \mathrm{~mm} \times 260 \mathrm{~mm}$ ) and Dadant hives (435 mm x $300 \mathrm{~mm}$ ). Ten bee colonies were placed in the vicinity of each oilseed rape field, throughout the rape florescence period (about 3 weeks). In each group, additionally 5 hives equipped with pollen traps were designated only for pollen loads collection. Two control groups (one in 2010 and one in 2012) were located in an area where no rape grew.
Before the experiments, the health status of each colony was estimated (April 2010, May 2012). Samples of about 300 adult bees were taken from the periphery combs of the brood nest and bees were analysed for the Varroa destructor (washing method), Nosema spp. (microscopic method) and the following viruses: chronic bee paralysis virus (CBPV), acute bee paralysis virus (ABPV), deformed wing virus (DWV), and Israeli acute paralysis virus (IAPV) (RT-PCR method, Pohorecka et al., 2011).

Each colony's population size was estimated before the experiments began (April 2010, May 2012) as well as every 3 weeks until the end of the beekeeping season. For this purpose, the number of combs covered by bees was counted and the brood area was measured. Bee mortality was monitored during the whole experiment, by counting the number of dead adults on hive bottom boards and $1 \times 1 \mathrm{~m}$ white trays set up on the ground in front of the hive entrances. Honey yield per colony

Table 1 .

The oilseed rape crops treatments

\begin{tabular}{|c|c|c|c|c|c|}
\hline $\begin{array}{l}\text { Group - field/ } \\
\text { treatment }\end{array}$ & $\begin{array}{c}\text { A } \\
\text { winter rape }\end{array}$ & $\begin{array}{c}\text { B } \\
\text { winter rape }\end{array}$ & $\begin{array}{c}\text { C } \\
\text { spring rape }\end{array}$ & $\begin{array}{c}\text { D } \\
\text { spring rape }\end{array}$ & $\begin{array}{c}E \\
\text { spring rape }\end{array}$ \\
\hline $\begin{array}{l}\text { Seed } \\
\text { dressing }\end{array}$ & $\begin{array}{c}\text { CRUISER } \\
\text { OSR } 322 \mathrm{FS}(\mathrm{l}, \mathrm{F})^{\star} \\
\text { thiamethoxam } 280 \mathrm{~g} \\
\text { metalaxyl-M } 32.15 \\
\text { g fludioxonil } 8 \mathrm{~g} / \mathrm{l} \\
\text { dose: } \\
11.25 \mathrm{ml} / \mathrm{kg} \text { seeds }\end{array}$ & $\begin{array}{c}\text { CHINOOK PLUS } \\
500 F S(I) \\
\text { imidacloprid } 420 \mathrm{~g} \\
\text { beta-cyfluthrin } 100 \mathrm{~g} / \mathrm{l} \\
\text { dose: } \\
5 \mathrm{ml} / \mathrm{kg} \text { seeds }\end{array}$ & $\begin{array}{c}\text { CRUISER } \\
\text { OSR 322 FS (I.F) } \\
\text { thiamethoxam 280g } \\
\text { metalaxyl-M } 32.15 \text {, } \\
\text { fludioxonil } 8 \mathrm{~g} / \mathrm{l} \\
\text { dose: } \\
11.25 \mathrm{ml} / \mathrm{kg} \text { seeds }\end{array}$ & $\begin{array}{c}\text { MODESTO } \\
480 \mathrm{FS}(\mathrm{l}) \\
\text { clothianidin } 400 \mathrm{~g} \\
\text { beta-cyfluthrin } 80 \mathrm{~g} / \mathrm{l} \\
\text { dose12.5 m/kg } \\
\text { seeds } \\
\text { FUNABENT } \\
480 \mathrm{FS}(\mathrm{F}) \\
\text { thiuram } 332 \mathrm{~g} \\
\text { carbendazim } 148 \mathrm{~g} / \mathrm{l} \\
\text { dose: } 5.5 \mathrm{ml} / \\
\mathrm{kg} \text { seeds }\end{array}$ & $\begin{array}{c}\text { CHINOOK } 200 \mathrm{FS}(\mathrm{l}) \\
\text { imidacloprid } 100 \mathrm{~g} \\
\text { beta-cyfluthrin } 100 \mathrm{~g} / \mathrm{l} \\
\text { dose: } 20 \mathrm{ml} / \mathrm{kg} \text { seeds } \\
\text { FUNABENT } \\
480 \mathrm{FS}(\mathrm{F}) \\
\text { thiuram } 332 \mathrm{~g} \\
\text { carbendazim } 148 \mathrm{~g} / \mathrm{l} \\
\text { dose: } 5.5 \mathrm{ml} / \mathrm{kg} \text { seeds }\end{array}$ \\
\hline $\begin{array}{l}\text { Spraying } \\
\text { during the } \\
\text { growing } \\
\text { period }\end{array}$ & $\begin{array}{c}\text { MOSPILAN 20 SP (I) } \\
\text { acetamiprid } 20 \% \\
\text { dose: } 0.1 \mathrm{~kg} / \mathrm{ha} \\
\text { spray: } 24.04 .2010 \\
\text { CYPERKILL } \\
\text { SUPER } 25 \mathrm{EC}(\mathrm{I}) \\
\text { cypermethrin } 250 \mathrm{~g} \\
\text { dose: } 0.15 \mathrm{l} / \mathrm{ha} \\
\text { spray: } 13.04 .2010\end{array}$ & $\begin{array}{c}\text { MOSPILAN } 20 \text { SP } \\
\text { acetamiprid } 20 \% \\
\text { dose: } 0.1 \mathrm{~kg} / \mathrm{ha} \\
\text { spray: } 18.04 .2010 \\
\text { PROTEUS } \\
110 \mathrm{OD}(\mathrm{I}) \\
\text { thiacloprid } 100 \mathrm{~g} \\
\text { deltamethrin } 10 \mathrm{~g} / \mathrm{l} \\
\text { dose: } 0.5 \mathrm{l} / \mathrm{ha} \\
\text { spray: } 18.04 .2010 \\
\text { CYPERKILL } \\
\text { SUPER } 25 \mathrm{EC} \\
\text { cypermethrin } 250 \mathrm{~g} \\
\text { dose: } 0.15 \mathrm{l} / \mathrm{ha} \\
\text { spray: } 10.04 .2010\end{array}$ & $\begin{array}{c}\text { PROTEUS } 110 \mathrm{OD} \\
\text { thiacloprid } 100 \mathrm{~g} \\
\text { detamethrin } 10 \mathrm{~g} / \mathrm{l} \\
\text { dose: } 0.5 \mathrm{l} / \mathrm{ha} \\
\text { spray: } 06.06 .2012 \\
\text { GALERA } 334 \mathrm{SL}(\mathrm{H})^{*} \\
\text { clopyralid } 267 \mathrm{~g} \\
\text { pikloram } 67 \mathrm{~g} / \mathrm{l} \\
\text { dose: } 0.35 \mathrm{l} / \mathrm{ha} \\
\text { spray: } 21.05 .2012 \\
\text { TARGA } 10 \mathrm{EC}(\mathrm{H})^{\star} \\
\text { quizalofop-p- } \\
\text { ethyl } 100 \mathrm{~g} / \mathrm{l} \\
\text { dose: } 1.0 \mathrm{l} / \mathrm{ha} \\
\text { spray: } 21.05 .2012\end{array}$ & $\begin{array}{c}\text { FURY } 100 \mathrm{EW}(\mathrm{I}) \\
\text { zeta-cypermethrin } \\
100 \mathrm{~g} / \mathrm{l} \\
\text { dose: } 0.1 \mathrm{l} / \mathrm{ha} \\
\text { spray: } 06.06 .2012 \\
\text { GALERA } 334 \mathrm{SL} \\
\text { clopyralid } 267 \mathrm{~g} \\
\text { pikloram } 67 \mathrm{~g} / \mathrm{l} \\
\text { dose: } 0.35 \mathrm{l} / \mathrm{ha} \\
\text { spray: } 20.05 .2012\end{array}$ & $\begin{array}{c}\text { PROTEUS } 110 \mathrm{OD} \\
\text { thiacloprid } 100 \mathrm{~g} \\
\text { deltamethrin } 10 \mathrm{~g} / \mathrm{l} \\
\text { dose: } 0.5 \mathrm{l} / \mathrm{ha} \\
\text { spray: } 05.06 .2012 \\
\text { FURY } 100 \mathrm{EW} \\
\text { azeta-cypermethrin } \\
100 \mathrm{~g} / \mathrm{l} \\
\text { dose: } 0.1 \mathrm{l} / \mathrm{ha} \\
\text { spray: } 08.05 .2012 \\
\text { GALERA } 334 \mathrm{SL} \\
\text { clopyralid } 267 \mathrm{~g} \\
\text { pikloram } 67 \mathrm{~g} / \mathrm{l} \\
\text { dose: } 0.35 \mathrm{l} / \mathrm{ha} \\
\text { spray: } 08.05 .2012\end{array}$ \\
\hline
\end{tabular}

*I-insecticide, $\mathrm{F}$ - fungicide, $\mathrm{H}$-herbicide 
was determined by weighing of harvested honey. In September 2010, bee colonies from experimental and control groups were prepared to overwintering. Each colony received approximately 18-20 liters of sugar solution. Biowar 500 (a.s. amitraz) and Apiwarol (a.s. amitraz) were used to protect the bee colonies against Varroa destructor. The status of the overwintered bee colonies (strength, brood area) was estimated in April of the following year.

\section{Collection of samples}

During the whole period of rape blooming which supplied forage for bees, samples of nectar directly from rape flowers were collected using a procedure described by Jabłoński (2002). Just before the flowering period, big $\left(16 \mathrm{~m}^{2}\right)$, airy, transparent isolators made from plastic netting were placed on each experimental field. The purpose was to keep secreted nectar isolated from nectareating insects. The samples were collected several times during the flowering period (min. 6 samples per one field) when the weather was sunny. Nectar flow from combs $(100 \mathrm{~g})$ was taken 7 and 14 days after the colonies were placed on the fields. Honey was harvested separately for each colony (from honey chambers only) about one week after the blooming period. The honey samples $(100 \mathrm{~g})$ were collected once from each container.

During the 3-week period all of the pollen loads that the bees had collected within a 3-4 day period were taken separately from the pollen traps of each of the 5 colonies intended for this purpose, and weighed. Samples of bee bread (app. $10 \times 10 \mathrm{~cm}$ pieces of combs) were taken once, after the blooming period. About 100 of bee workers were taken from brood chamber one time, after the oilseed rape blooming period.

Samples of nectar, honey and pollen were split in two parts. One part was for the pollen analysis and one for the residue analysis. All collected samples were frozen and stored at a low temperature of about $-20^{\circ} \mathrm{C}$.

\section{Palynological analysis}

Analyses of pollen loads, bee bread, and honey were performed separately for each colony and harvest date. Before conducting the analysis, each sample of pollen loads and bee bread was mixed for color uniformity, and about $20 \mathrm{~g}$ were put into screw-capped plastic containers with $20 \mathrm{ml}$ of distilled water. After obtaining a homogeneous suspension, microscopic slides were prepared. Pollen analyses of the collected material were performed using the biological microscope Olympus BX41 under 400x magnification. In each microscopic slide, in successive view fields of the microscope, all the pollen grains of each plant species were counted separately, until the total number of 300 grains was exceeded. The percentage content of every pollen type was calculated.

Pollen analysis of nectar flow and honey was performed according to the methodology recommended by the International Commission of Bee Botany, and the International Honey Commission (Louveaux et al., 1978).

\section{Residue analysis}

\section{Reagents and materials}

The standards of the five neonicotinoid insecticides (imidacloprid, clothianidin, thiametoxam, acetamiprid and thiacloprid) had purity $\geq 93.3 \%$ (typically $>99 \%$ ) and were purchased from Fluka, SigmaAldrich, Promochem (Institut of Industrial Organic Chemistry), Dr. Ehrenstorfer, Riedel-de Haen and Supelco. Ultra gradient HPLC - grade acetonitrile and water were purchased from Carlo Erba. Anhydrous magnesium sulfate (grit and powder), sodium choride, sodium citrate tribasic, sodium hydrogencitrate sesquihydrate were ordered from Sigma-Aldrich. Acetic acid (HOAc) (98\% purity), n-heksan (99\% purity) were obtained from Chempur. Formic acid (98\% purity) was purchased from J.T. Baker, ammonium formate was from Fluka. Both of SPE sorbents PSA bonded (primary secondary amine) and Discovery DSC-18 were obtained from Supelco. Triphenylphosphate (TPP) and Tri (2,3-dichloropropyl) phosphate (TDCPP) were purchased from Fluka. 
Standard solution preparation

Individual standard stock solutions at $1000 \mu \mathrm{g} / \mathrm{ml}$ were prepared by dissolving standards in acetonitrile, methanol or acetone depending on the solubility of particular pesticide and were stored in amber glass flasks at $-18^{\circ} \mathrm{C}$. A working standard pesticide mixture at $10 \mu \mathrm{g} / \mathrm{ml}$ in acetonitril (acidified with $0.1 \%$ HOAc $(\mathrm{v} / \mathrm{v}))$ was prepared from the stock solutions and kept at $4^{\circ} \mathrm{C}$ before use. This mixture was appropriately diluted in acetonitril $(\mathrm{MeCN})$ to prepare matrixmatched calibration and fortification standards. TPP was prepared at $0.5 \mu \mathrm{g} / \mathrm{ml}$ in $\mathrm{MeCN}$ (acidified 0.1\% HOAc (v/v)), and was added to the final extracts, blanks and matrix - matched calibration. A solution of $50 \mu \mathrm{g} / \mathrm{ml}$ TDCPP in MeCN (surrogate standard), was added during the entire procedure and was used to control extraction step.

\section{Sample preparation}

The sample preparation procedure based on a modified "QuEChERS" method (Anastassiades and Lehotay, 2003; Wiest et al., 2010) was used and consisted of the following steps: (1) weighing the sample (honey, nectar - $10 \mathrm{~g}$; pollen, bee bread, bees - $5 \mathrm{~g}$ each) in a $50 \mathrm{ml}$ teflon centrifuge tube; (2) adding $100 \mu \mathrm{l}$ of (surrogate standard) TDCPP and vortexing the tube for $1 \mathrm{~min}$; (3) adding $10 \mathrm{ml}$ of deionised water and shaking the tube vigorously for $20 \mathrm{~s}$; (4) adding $10 \mathrm{ml}$ of acetonitrile and $2 \mathrm{ml}$ of n-hexane than vortexing the tube for $1 \mathrm{~min}$; (5) adding $4 \mathrm{~g}$ of anhydrous magnesium sulphate $\left(\mathrm{MgSO}_{4}\right), 1 \mathrm{~g}$ sodium chloride, $1 \mathrm{~g}$ sodium citrate tribasic, $0.5 \mathrm{~g}$ sodium hydrogencitrate sesquihydrate and shaking the tube immediately and vigorously for $1 \mathrm{~min}$ by hand to prevent the agglomeration of magnesium sulfate salts; (7) centrifuging the tube at $7100 \mathrm{rpm}$ for 5 minutes; (8) transferring $1 \mathrm{ml}$ of $\mathrm{MeCN}$ supernatant to the dSPE tube containing $240 \mathrm{mg}$ anhydrous $\mathrm{MgSO}_{4}+50 \mathrm{mg}$ PSA $+50 \mathrm{mg} \mathrm{C} 18$ and mixing the extract and vortexing for $1 \mathrm{~min}$; (9) centrifuging the dSPE tube for $1 \mathrm{~min}$ at $8600 \mathrm{rpm}$;
(10) transferring $250 \mu \mathrm{l}$ of extract into $2 \mathrm{ml}$ Eppendorf probe, adding $750 \mu \mathrm{l}$ of water, adding $50 \mu \mathrm{l}$ of acetonitrile and $50 \mu \mathrm{l}$ internal standard TPP, mixing vigorously and filtering it, using $0.45 \mu \mathrm{m}$ syringe filter, direct to a HPLC vial. The final extract was analysed by LC/MS/ MS. For the matrix-matched standard calibration, "blank" matrix of nectar, pollen loads, bee bread, honey, bees were used. $50 \mu$ l of particular working standard mixture and $50 \mu \mathrm{l}$ TPP were added to 1 $\mathrm{ml}$ blank extracts prepared as for analysis of samples. This method of calibration compensate of matrix effects.

\section{LC-MS analysis}

For the LC analysis, an Agilent 1200 HPLC system with a binary pump was used. The analytes were separated on $\mathrm{C} 18$ analytical column of $100 \mathrm{~mm} 2.1 \mathrm{~mm}$ and $1.8 \mu \mathrm{m}$ particle size (Agilent Zorbax Eclipse Plus). Column temperature was maintained at $45^{\circ} \mathrm{C}$. The injected sample volume was $10 \mu \mathrm{l}$. The mobile phases were: A - water containing $0.01 \%$ formic acid and $5 \mathrm{mM}$ ammonium formate and $\mathrm{B}$ mixture of acetonitrile - water $(95+5, \mathrm{v} / \mathrm{v})$ containing $0.01 \%$ formic acid and $5 \mathrm{mM}$ ammonium formate. The gradient program started with $20 \% \mathrm{~B}$, constant for $1 \mathrm{~min}$, followed by a linear gradient up to $100 \%$ $\mathrm{B}$ in $18 \mathrm{~min}$, then constant for $2 \mathrm{~min}$. After this 20-min run time, 7 min of posttime followed using the initial $20 \%$ of $\mathrm{B}$. The flow rate was constant, $0.3 \mathrm{ml} / \mathrm{min}$ during the whole process. For the mass spectrometric analysis, an Agilent 6410 Triple-Quad LC/MS system was applied. The ESI source was operated in positive ionization mode and its parameters were as follows: gas temperature, $325^{\circ} \mathrm{C}$; gas flow, 9 1/min; nebulizer gas, $40 \mathrm{psi}$; capillary Voltage, $4000 \mathrm{~V}$. The data recorded was processed with the Mass Hunter software.

\section{Validation parameters}

The determination of neonicotinoides was performed by LC-MS/MS. The method for the analysis of pesticides in bee collected plant material was prepared according to the requirements of guideline SANCO/825/00 rev 8.1 "Guidance 
document of pesticide residue analytical methods" from 16.11.2010. Mean recovery efficiencies for all collected matrices were from $70-110 \%$ and the relative standard deviation was less than $20 \%$ thus demonstrating sufficient accuracy and precision of the method. The LODs were estimated from the injection of matrixmatched solutions at concentration levels corresponding to a signal-to-noise ratio of about 3 for the quantitation ion and presence of the confirmatory ion as well. LODs levels for nectar and pollen samples are included in Table 2. During validation linearity of the method was evaluated in matrix-matched standards for each matrix. The calibration where found to be linear with correlation coefficients greater than 0.99 for pesticides included in method.

\section{Statistical analysis}

All statistical analyses were carried out using Statistica 8 software. The means were tested using the Student's t-test or the ANOVA test, and multiple comparisons with Tukey test. Comparisons of parameters for non-parametric groups were conducted using the Mann-Whitney U-test or the Kruskal-Wallis test on a significance level of $\alpha=0.05$. Spearman's rank correlation was used to assess the relationship between variables. For all analyses, p-value $<0.05$ was considered significant.

\section{RESULTS}

\subsection{Residue analysis}

Each neonicotinoid insecticide used for protecting oilseed rape crops was found in the examined matrix. A substantial number of samples was additionally contaminated with neonicotinoids which had not been applied as preventative measures in oilseed rape fields. Of the 5 examined compounds, the most frequently detected were thiamethoxam, thiacloprid, and acetamiprid. Residues from these substances were present in 65,64 , and $51 \%$ of the total nectar and honey samples, respectively. Share of the positive pollen samples was 37,62 , and $45 \%$, respectively (Tab. 5).

1.1.1 The residues of neonicotinoids used as seed treatment

In samples from winter oilseed rape treated with thiamethoxam (field A), this neonicotinoid was detected in nectar flow from combs and honey. The levels of residues in all samples were similar and ranged from 1.3 to $2.6 \mathrm{ng} / \mathrm{g}$. Thiamethoxam was not identified in any pollen or nectar sample collected directly from flowers. However, in the material collected from spring rape (field $\mathrm{C}$ ), thiamethoxam was present in all of the samples (Tab. 6 and 7). Nectar collected directly from flowers, nectar flow from combs and honey showed from 3.2 to $12.9 \mathrm{ng} / \mathrm{g}$ of thiamethoxam. The range of residues in pollen loads and bee bread was similar ( 2.0 to $9.9 \mathrm{ng} / \mathrm{g}$ ). The average content $(8.7 \mathrm{ng} / \mathrm{g})$ in both nectar and honey samples together was significantly higher (Mann-Whitney U-test $\mathrm{p}<0.00001)$ from the average content in pollen loads and bee bread $(5.7 \mathrm{ng} / \mathrm{g})$. The levels of thiamethoxam residues in pollen loads and bee bread samples depended on the percentage of Brassica napus pollen in

Table 2 .

Limits of detection (LOD) and quantification (LOQ) for nectar, honey, pollen, bee bread and bees for analysis of the 5 neonicotinoid pesticides

\begin{tabular}{||c|c|c|c||}
\hline \multirow{2}{*}{ Name } & Nectar and Honey & $\begin{array}{c}\text { Pollen and } \\
\text { Bee bread }\end{array}$ & Bees \\
\cline { 2 - 4 } & LOD/LOQ $(\mathrm{ng} / \mathrm{g})$ & $\mathrm{LOD} / \mathrm{LOQ}(\mathrm{ng} / \mathrm{g})$ & LOD/LOQ $(\mathrm{ng} / \mathrm{g})$ \\
\hline Acetamiprid & $0.1 / 0.5$ & $0.2 / 1$ & $0.3 / 1$ \\
\hline Clothianidin & $0.5 / 2$ & $1 / 3$ & $2 / 6$ \\
\hline Imidacloprid & $0.2 / 1$ & $0.8 / 3$ & $0.5 / 2$ \\
\hline Thiacloprid & $0.1 / 0.5$ & $0.4 / 2$ & $0.1 / 0.5$ \\
\hline Thiamethoxam & $0.1 / 0.5$ & $0.3 / 1.5$ & $1 / 3$ \\
\hline
\end{tabular}


the total mass of the samples (Spearman rank order correlation $\mathrm{Rs}=0.645)$. The average amount of thiamethoxam $(8.7 \mathrm{ng} / \mathrm{g})$ in nectar flow and honey collected from spring rape (field C) was significantly higher (Mann-Whitney U-test $\mathrm{p}<0.00001$ ) than the average amount of thiamethoxam $(1.6 \mathrm{ng} / \mathrm{g})$ in nectar flow from combs and honey from winter rape.

Clothianidin, used only to dress seeds of spring rape (field D), was detected in the majority of nectar, honey and pollen samples. The amounts of clothianidin ranged from 1.0 to $4.0 \mathrm{ng} / \mathrm{g}$ (Tab. 6 and 7). The average contamination level of nectar and honey samples combined, turned out to be significantly higher (Mann-Whitney U-test $\mathrm{p}<0.00001)$ than the contamination of pollen (pollen loads and bee bread together) and amounted to 2.1 and $1.1 \mathrm{ng} / \mathrm{g}$, respectively.

The analysis of samples originating from winter oilseed rape crops that had been protected with imidacloprid (field B), showed the average of $0.6 \mathrm{ng} / \mathrm{g}$ of this compound in nectar flow and honey, and $0.8 \mathrm{ng} / \mathrm{g}$ in pollen (Tab. 6 and 7). A similar amount was detected in only 2 samples of nectar flow from spring oilseed rape crop (field E). Imidacloprid was not found in pollen samples, regardless of the content of Brassica napus pollen.

Even though imidacloprid, clothianidin and thiamethoxam residues were found in nectar, honey and pollen, they were not detected in the samples of bees themselves collected from the hives.

\subsubsection{The residues of neonicotinoids} used as spray treatment

After spraying winter oilseed rape fields with acetamiprid, the level of residues in nectar and honey ranged from 0.1 to $7.6 \mathrm{ng} / \mathrm{g}$, while in pollen loads and bee bread samples from 0.6 to $10.5 \mathrm{ng} / \mathrm{g}$ (Tab. 6 and 7). The average amounts of acetamiprid in pollen (both pollen loads and bee bread together) and nectar (nectar, nectar flow, and honey) did not differ significantly (Mann-Whitney U-test $\mathrm{p}=0.827$ ) and amounted to 3.4 and $3.8 \mathrm{ng} / \mathrm{g}$, respectively.

However, a significant difference (MannWhitney U-test $\mathrm{p}<0.00001$ ) occurred between the contamination level of samples from the field sprayed a week before the

Contents of Brassica napus pollen in different types of samples collected from honeybee colonies placed in the rape crops $(2010,2012)$

\begin{tabular}{|c|c|c|c|c|c|}
\hline \multirow{2}{*}{ Field } & \multirow{2}{*}{$\begin{array}{l}\text { Period of blooming; period } \\
\text { of supplying forage }\end{array}$} & \multicolumn{4}{|c|}{ Average content of Brassica napus pollen grains ( $\% \pm$ sd) } \\
\hline & & Pollen loads & Bee bread & Nectar flow & Honey \\
\hline A-winter rape & \multirow{2}{*}{$30.04-21.05 .10$} & $92.3 \pm 4.6$ & $25.3 \pm 19.3$ & $52.7 \pm 19.0$ & $31.7 \pm 21.6$ \\
\hline B-winter rape & & $6.0 \pm 2.3$ & $33.4 \pm 26.9$ & $49.1 \pm 22.7$ & $51.3 \pm 13.9$ \\
\hline C-spring rape & \multirow{3}{*}{ 14.06-02.07.12 } & $98.0 \pm 1.9$ & $74.6 \pm 5.6$ & $67.2 \pm 19.6$ & $79.4 \pm 12.8$ \\
\hline D-spring rape & & $85.1 \pm 12.2$ & $60.5 \pm 11.6$ & $61.2 \pm 14.2$ & $84.2 \pm 8.4$ \\
\hline E-spring rape & & $78.3 \pm 16.3$ & $48.7 \pm 18.7$ & $75.7 \pm 10.3$ & $67.2 \pm 14.4$ \\
\hline
\end{tabular}

Table 4

Botanical origin of nectar and pollen flow harvested by honeybee colonies from the control groups - results of pollen analysis $(2010,2012)$

\begin{tabular}{||c|c|c||}
\hline Control group/year & Type of sample & Predominant pollen (>10\%) \\
\hline \multirow{2}{*}{$\begin{array}{c}\text { Control group } \\
\text { in 2010 }\end{array}$} & $\begin{array}{c}\text { Nectar flow, } \\
\text { honey }\end{array}$ & $\begin{array}{c}\text { Prunus type, Malus type, Brassica napus, Rubus type, } \\
\text { Aesculus, Salix, Brassicaceae, Asteraceae, }\end{array}$ \\
\cline { 2 - 3 } & $\begin{array}{c}\text { Pollen loads, } \\
\text { bee bread }\end{array}$ & $\begin{array}{c}\text { Prunus type, Malus type, Rubus type, Aesculus, } \\
\text { Salix, Brassicaceae, Asteraceae, Fragaria }\end{array}$ \\
\hline \multirow{2}{*}{$\begin{array}{c}\text { Control group } \\
\text { in 2012 }\end{array}$} & $\begin{array}{c}\text { Nectar flow, } \\
\text { honey }\end{array}$ & $\begin{array}{c}\text { Tilia, Brassicaceae, Fagopyrum, Trifolium repens, Phacelia, } \\
\text { Prunus type, Rubus type, Anthriscus type, Brassica napus }\end{array}$ \\
\cline { 2 - 3 } & $\begin{array}{c}\text { Pollen loads, } \\
\text { bee bread }\end{array}$ & $\begin{array}{c}\text { Trifolium repens, Brassica napus, Phacelia, Fagopyrum, Brassicaceae, } \\
\text { Tilia, Rubus type, Anthriscus type, Achillea type, Prunus type, }\end{array}$ \\
\hline
\end{tabular}


Table 5 .

Neonicotinoids incidence and level of their concentration $(\mathrm{ng} / \mathrm{g})$ in analyzed samples collected from winter and spring oilseed rape $(2010,2012)$

\begin{tabular}{|c|c|c|c|c|c|c|c|c|}
\hline \multirow[t]{2}{*}{$\begin{array}{c}\text { active } \\
\text { substance }\end{array}$} & \multicolumn{4}{|c|}{$\begin{array}{c}\text { Samples of nectar } \\
\text { ( } \sum \text { samples of nectar from flowers and } \\
\text { combs, honey) } \\
n=212\end{array}$} & \multicolumn{4}{|c|}{$\begin{array}{c}\text { Samples of pollen } \\
\text { ( } \Sigma \text { samples of pollen loads and bee } \\
\text { bread ) } \\
n=205\end{array}$} \\
\hline & $\%$ positive & mean & $\max$ & median & $\%$ positive & mean & $\max$ & median \\
\hline imidacloprid & 21 & 0.6 & 2.0 & 0.6 & 0 & 0 & 0 & 0 \\
\hline clothianidin & 17 & 2.3 & 10.1 & 1.6 & 11 & 1.8 & 3.7 & 1.2 \\
\hline thiamethoxam & 65 & 4.2 & 12.9 & 3.1 & 37 & 3.8 & 9.9 & 2.9 \\
\hline acetamiprid & 51 & 2.4 & 13.3 & 1.1 & 45 & 4.1 & 26.1 & 2.5 \\
\hline thiacloprid & 64 & 6.5 & 208.8 & 2.5 & 62 & 89.1 & 1002.2 & 4.1 \\
\hline
\end{tabular}

bee colonies were placed there (field A) The analysis of nectar and pollen samples and contamination level of samples from the field sprayed 2 weeks before the bee colonies were placed there (field B). The average content of acetamiprid (for all the kinds of samples combined) was 7.7 and $0.2 \mathrm{ng} / \mathrm{g}$, respectively.

Thiacloprid was sprayed on 3 different spring rape plantations in the same dosages and at the same time. However, thiacloprid contents, even in samples of the same kind, varied greatly. It was not detected in any of the samples of nectar collected directly from flowers from field E. In some nectar samples from field $\mathrm{C}$ the average detected content of thiacloprid was $0.9 \mathrm{ng} / \mathrm{g}$. In nectar samples from field B the average value of thiacloprid was $65.6 \mathrm{ng} / \mathrm{g}$. The amounts of thiacloprid in bee bread samples from these fields differed as well (Tab. 6 and 7).

The thiacloprid content in pollen samples (pollen loads and bee bread) of the 3 combined fields did not differ significantly (Mann-Whitney U-test $\mathrm{p}=0.192$ ) from the thiacloprid content of the combined nectar, and honey samples.

1.1.3 The residues of neonicotinoids which had not been applied as preventative measures in oilseed rape fields but from which the residues were still detected in samples

Acetamiprid and/or thiacloprid were detected in a great number of nectar samples and in part of the pollen samples from every oilseed rape crop. Almost all nectar and honey samples from 2 spring rape crops (field D and E) contained thiamethoxam. from the control colonies proved the presence of acetamiprid and thiacloprid as well (Tab. 6 and 7). The residue levels of these substances, however, were low in the majority of samples.

\subsubsection{The residues of pesticides from} other chemical groups

The use of multi-residue method allowed us to find the other pesticides. In addition, the fourteen of active ingredients of fungicides and herbicides have been detected in the 2012 analyzed samples. The most common compounds were carbendazim, metalaxil, spiroxamine, lenacil, thiophanate-methyl, tebuconazole, and dimethoate. Some samples showed high concentrations of lenacil and thiophanate-methyl (Tab. 8). Just some of these pesticides had been used to protect the spring oilseed rape crops.

1.2 Honeybee colony assessment

\subsubsection{The health status and population} size

During routine inspections of colonies no clinical symptoms of any diseases were found and this was confirmed by laboratory analysis. The level of $V$. destructor infestation was so low that no mites were detected in the samples of bees. The level of Nosema spp. infection was also low and did not differ significantly between groups (Kruskal-Wallis test $\mathrm{H}=0.461 \mathrm{p}=0.793$ for 2010, $\mathrm{H}=6.355 \mathrm{p}=0.095$ for 2012). The mean number of Nosema spores per sampled bees in colonies from A, B, C, D, E groups amounted to $3.4 ; 2.1 ; 0.03 ; 0.02$, and $0.1 \times 10^{6}$, respectively. In the majority of 
Table 6.

Incidence of neonicotinoids and level of their concentration $(\mathrm{ng} / \mathrm{g})$ in analyzed samples collected from winter rape (2010)

\begin{tabular}{|c|c|c|c|c|c|c|c|c|c|c|c|c|}
\hline \multirow{2}{*}{\multicolumn{2}{|c|}{$\begin{array}{l}\text { Field/analyzed } \\
\text { samples }\end{array}$}} & \multirow[b]{2}{*}{$\mathrm{n}$} & \multicolumn{2}{|c|}{ Imidacloprid } & \multicolumn{2}{|c|}{ Clothianidin } & \multicolumn{2}{|c|}{ Thiamethoxam } & \multicolumn{2}{|c|}{ Acetamiprid } & \multicolumn{2}{|c|}{ Thiacloprid } \\
\hline & & & $\begin{array}{c}\% \\
\text { pos. }\end{array}$ & $\begin{array}{l}\text { Mean } \\
\pm \text { sd }\end{array}$ & $\begin{array}{c}\% \\
\text { pos. }\end{array}$ & $\begin{array}{l}\text { Mean } \\
\pm \text { sd }\end{array}$ & $\begin{array}{c}\% \\
\text { pos. }\end{array}$ & $\begin{array}{l}\text { Mean } \\
\pm \text { sd }\end{array}$ & $\begin{array}{c}\% \\
\text { pos. }\end{array}$ & $\begin{array}{l}\text { Mean } \\
\pm \text { sd }\end{array}$ & $\begin{array}{c}\% \\
\text { pos. }\end{array}$ & $\begin{array}{c}\text { Mean } \\
\pm s d\end{array}$ \\
\hline A & $\begin{array}{l}\text { Nectar ff* } \\
\text { Nectar fc }{ }^{\star *} \\
\text { Honey } \\
\text { Pollen loads } \\
\text { Bee bread } \\
\text { Bees } \\
\end{array}$ & $\begin{array}{l}6 \\
10 \\
10 \\
20 \\
10 \\
10\end{array}$ & $\begin{array}{c}0 \\
100 \\
100 \\
0 \\
0 \\
0 \\
\end{array}$ & $\begin{array}{l}\text { nd } \\
0.5 \pm 0.1 \\
0.5 \pm 0.1 \\
\text { nd } \\
\text { nd } \\
\text { nd } \\
\end{array}$ & $\begin{array}{l}0 \\
0 \\
0 \\
0 \\
0 \\
0\end{array}$ & $\begin{array}{l}\text { nd } \\
\text { nd } \\
\text { nd } \\
\text { nd } \\
\text { nd } \\
\text { nd }\end{array}$ & $\begin{array}{c}0 \\
100 \\
100 \\
0 \\
0 \\
0\end{array}$ & $\begin{array}{l}\text { nd } \\
2.4 \pm 0.2 \\
1.8 \pm 0.3 \\
\text { nd } \\
\text { nd } \\
\text { nd } \\
\end{array}$ & $\begin{array}{l}100 \\
100 \\
100 \\
100 \\
100 \\
90 \\
\end{array}$ & $\begin{array}{c}7.6 \pm 2.9 \\
6.8 \pm 0.5 \\
6.8 \pm 0.7 \\
10.5 \pm 2.4 \\
4.7 \pm 1.9 \\
0.3 \pm 0.2 \\
\end{array}$ & $\begin{array}{c}0 \\
0 \\
100 \\
0 \\
100 \\
0\end{array}$ & $\begin{array}{c}\text { nd } \\
\text { nd } \\
0.3 \pm 0.3 \\
\text { nd } \\
0.8 \pm 1.3 \\
\text { nd } \\
\end{array}$ \\
\hline B & $\begin{array}{l}\text { Nectar ff* } \\
\text { Nectar fc }{ }^{\star \star} \\
\text { Honey } \\
\text { Pollen loads } \\
\text { Bee bread } \\
\text { Bees }\end{array}$ & $\begin{array}{l}7 \\
10 \\
10 \\
20 \\
10 \\
10\end{array}$ & $\begin{array}{c}0 \\
100 \\
100 \\
0 \\
0 \\
0\end{array}$ & $\begin{array}{l}\text { nd } \\
0.6 \pm 0.1 \\
0.8 \pm 0.3 \\
\text { nd } \\
\text { nd } \\
\text { nd }\end{array}$ & $\begin{array}{l}0 \\
0 \\
0 \\
0 \\
0 \\
0\end{array}$ & $\begin{array}{l}\text { nd } \\
\text { nd } \\
\text { nd } \\
\text { nd } \\
\text { nd } \\
\text { nd }\end{array}$ & $\begin{array}{l}0 \\
0 \\
0 \\
0 \\
0 \\
0\end{array}$ & $\begin{array}{l}\text { nd } \\
\text { nd } \\
\text { nd } \\
\text { nd } \\
\text { nd } \\
\text { nd }\end{array}$ & $\begin{array}{c}0 \\
100 \\
100 \\
0 \\
100 \\
0\end{array}$ & $\begin{array}{c}\text { nd } \\
0.1 \pm 0.02 \\
0.1 \pm 0.03 \\
\text { nd } \\
0.6 \pm 1.1 \\
\text { nd }\end{array}$ & $\begin{array}{l}100 \\
100 \\
100 \\
100 \\
100 \\
100\end{array}$ & $\begin{array}{c}65.6 \pm 75.7 \\
5.5 \pm 1.3 \\
5.5 \pm 0.8 \\
3.1 \pm 0.7 \\
2.7 \pm 1.4 \\
0.4 \pm 0.3\end{array}$ \\
\hline K1 & $\begin{array}{l}\text { Nectar fc }{ }^{\star *} \\
\text { Honey } \\
\text { Pollen loads } \\
\text { Bee bread } \\
\text { Bees }\end{array}$ & $\begin{array}{l}10 \\
10 \\
20 \\
10 \\
10\end{array}$ & $\begin{array}{l}0 \\
0 \\
0 \\
0 \\
0\end{array}$ & $\begin{array}{l}\text { nd } \\
\text { nd } \\
\text { nd } \\
\text { nd } \\
\text { nd }\end{array}$ & $\begin{array}{l}0 \\
0 \\
0 \\
0 \\
0\end{array}$ & $\begin{array}{l}\text { nd } \\
\text { nd } \\
\text { nd } \\
\text { nd } \\
\text { nd }\end{array}$ & $\begin{array}{l}0 \\
0 \\
0 \\
0 \\
0\end{array}$ & $\begin{array}{l}\text { nd } \\
\text { nd } \\
\text { nd } \\
\text { nd } \\
\text { nd }\end{array}$ & $\begin{array}{c}100 \\
100 \\
0 \\
100 \\
100\end{array}$ & $\begin{array}{c}0.2 \pm 0.1 \\
0.1 \pm 0.1 \\
\text { nd } \\
0.1 \pm 0.1 \\
0.3 \pm 0.2\end{array}$ & $\begin{array}{l}100 \\
100 \\
100 \\
100 \\
100 \\
\end{array}$ & $\begin{array}{c}3.4 \pm 1.6 \\
2.3 \pm 1.6 \\
646.0 \pm 274.0 \\
25.6 \pm 14.2 \\
0.1 \pm 0.03\end{array}$ \\
\hline
\end{tabular}

*nectar collected directly from rape flowers;

** nectar flow from combs; K1- the control group; nd - not detected

- red color indicates substances used as seed dressing or as a spray.

Table 7 .

Incidence of neonicotinoids and level of their concentration (ng/g) in analyzed samples collected from spring rape (2012)

\begin{tabular}{|c|c|c|c|c|c|c|c|c|c|c|c|c|}
\hline \multirow{2}{*}{\multicolumn{2}{|c|}{$\begin{array}{l}\text { Field/analyzed } \\
\text { samples }\end{array}$}} & \multirow[b]{2}{*}{$\mathrm{n}$} & \multicolumn{2}{|c|}{ Imidacloprid } & \multicolumn{2}{|c|}{ Clothianidin } & \multicolumn{2}{|c|}{ Thiamethoxam } & \multicolumn{2}{|c|}{ Acetamiprid } & \multicolumn{2}{|c|}{ Thiacloprid } \\
\hline & & & $\begin{array}{c}\% \\
\text { pos. }\end{array}$ & $\begin{array}{c}\text { mean } \\
\pm \text { sd }\end{array}$ & $\begin{array}{c}\% \\
\text { pos. }\end{array}$ & $\begin{array}{c}\text { mean } \\
\pm s d\end{array}$ & $\begin{array}{c}\% \\
\text { pos. }\end{array}$ & $\begin{array}{c}\text { mean } \\
\pm s d\end{array}$ & $\begin{array}{c}\% \\
\text { pos. }\end{array}$ & $\begin{array}{l}\text { mean } \\
\pm s d\end{array}$ & $\begin{array}{c}\% \\
\text { pos. }\end{array}$ & $\begin{array}{l}\text { mean } \\
\text { 土sd }\end{array}$ \\
\hline $\mathrm{C}$ & $\begin{array}{l}\text { Nectar ff* } \\
\text { Nectar fc ** } \\
\text { Honey } \\
\text { Pollen loads } \\
\text { Bee bread } \\
\text { Bees } \\
\end{array}$ & \begin{tabular}{l|}
7 \\
20 \\
10 \\
25 \\
10 \\
10 \\
\end{tabular} & $\begin{array}{l}0 \\
0 \\
0 \\
0 \\
0 \\
0 \\
\end{array}$ & $\begin{array}{l}\text { nd } \\
\text { nd } \\
\text { nd } \\
\text { nd } \\
\text { nd } \\
\text { nd }\end{array}$ & $\begin{array}{l}0 \\
0 \\
0 \\
0 \\
0 \\
0 \\
\end{array}$ & $\begin{array}{l}\text { nd } \\
\text { nd } \\
\text { nd } \\
\text { nd } \\
\text { nd } \\
\text { nd }\end{array}$ & $\begin{array}{c}100 \\
100 \\
100 \\
100 \\
100 \\
0\end{array}$ & $\begin{array}{c}5.4 \pm 3.7 \\
10.3 \pm 2.3 \\
7.7 \pm 2.8 \\
6.6 \pm 2.0 \\
3.6 \pm 1.5 \\
\text { nd } \\
\end{array}$ & $\begin{array}{c}14 \\
0 \\
70 \\
0 \\
80 \\
0 \\
\end{array}$ & $\begin{array}{c}0.2 \pm 0.6 \\
\text { nd } \\
0.7 \pm 0.5 \\
\text { nd } \\
7.6 \pm 9.1 \\
\text { nd } \\
\end{array}$ & \begin{tabular}{c|}
43 \\
95 \\
100 \\
100 \\
100 \\
0 \\
\end{tabular} & $\begin{array}{c}0.9 \pm 1.6 \\
2.8 \pm 1.4 \\
2.1 \pm 0.4 \\
81.6 \pm 123.6 \\
21.8 \pm 25.8 \\
\text { nd }\end{array}$ \\
\hline $\mathrm{D}$ & $\begin{array}{c}\text { Nectar ff* } \\
\text { Nectar fc** } \\
\text { Honey } \\
\text { Pollen loads } \\
\text { Bee bread } \\
\text { Bees }\end{array}$ & \begin{tabular}{l|}
6 \\
20 \\
10 \\
20 \\
10 \\
10
\end{tabular} & $\begin{array}{l}0 \\
0 \\
0 \\
0 \\
0 \\
0\end{array}$ & $\begin{array}{l}\text { nd } \\
\text { nd } \\
\text { nd } \\
\text { nd } \\
\text { nd } \\
\text { nd }\end{array}$ & $\begin{array}{c}50 \\
100 \\
100 \\
50 \\
90 \\
0\end{array}$ & $\begin{array}{c}2.6 \pm 4.0 \\
1.3 \pm 0.3 \\
3.4 \pm 1.0 \\
0.6 \pm 0.6 \\
2.2 \pm 1.3 \\
\text { nd }\end{array}$ & $\begin{array}{c}100 \\
100 \\
100 \\
50 \\
90 \\
0\end{array}$ & $\begin{array}{c}2.7 \pm 1.1 \\
3.3 \pm 0.3 \\
3.9 \pm 0.5 \\
0.6 \pm 0.7 \\
1.0 \pm 0.4 \\
\text { nd }\end{array}$ & $\begin{array}{c}0 \\
0 \\
30 \\
20 \\
30 \\
0\end{array}$ & $\begin{array}{c}\text { nd } \\
\text { nd } \\
0.3 \pm 0.5 \\
0.2 \pm 0.6 \\
0.8 \pm 1.4 \\
\text { nd }\end{array}$ & $\begin{array}{c}67 \\
25 \\
0 \\
0 \\
20 \\
0\end{array}$ & $\begin{array}{c}3.8 \pm 4.5 \\
0.3 \pm 0.6 \\
\text { nd } \\
\text { nd } \\
0.4 \pm 0.9 \\
\text { nd }\end{array}$ \\
\hline$E$ & $\begin{array}{c}\text { Nectar ff* } \\
\text { Nectar fc }{ }^{\star *} \\
\text { Honey } \\
\text { Pollen loads } \\
\text { Bee bread } \\
\text { Bees } \\
\end{array}$ & \begin{tabular}{l|}
6 \\
20 \\
10 \\
15 \\
10 \\
10 \\
\end{tabular} & $\begin{array}{c}0 \\
10 \\
0 \\
0 \\
0 \\
0\end{array}$ & $\begin{array}{c}\text { nd } \\
0.4 \pm 0.7 \\
\text { nd } \\
\text { nd } \\
\text { nd } \\
\text { nd } \\
\end{array}$ & $\begin{array}{l}0 \\
0 \\
0 \\
0 \\
0 \\
0\end{array}$ & $\begin{array}{l}\text { nd } \\
\text { nd } \\
\text { nd } \\
\text { nd } \\
\text { nd } \\
\text { nd }\end{array}$ & $\begin{array}{c}83 \\
100 \\
100 \\
0 \\
0 \\
0\end{array}$ & $\begin{array}{c}1.1 \pm 0.6 \\
1.5 \pm 0.3 \\
1.2 \pm 0.2 \\
\text { nd } \\
\text { nd } \\
\text { nd } \\
\end{array}$ & $\begin{array}{c}0 \\
50 \\
100 \\
0 \\
50 \\
0 \\
\end{array}$ & $\begin{array}{c}\text { nd } \\
2.7 \pm 0.7 \\
1.2 \pm 0.1 \\
\text { nd } \\
1.9 \pm 3.1 \\
\text { nd } \\
\end{array}$ & $\begin{array}{c}0 \\
60 \\
90 \\
0 \\
60 \\
0 \\
\end{array}$ & $\begin{array}{c}\text { nd } \\
2.1 \pm 2.3 \\
1.8 \pm 0.9 \\
\text { nd } \\
7.5 \pm 15.2 \\
\text { nd } \\
\end{array}$ \\
\hline $\mathrm{K} 2$ & $\begin{array}{l}\text { Nectar fc }^{* \star} \\
\text { Honey } \\
\text { Pollen loads } \\
\text { Bee bread } \\
\text { Bees }\end{array}$ & $\begin{array}{l}20 \\
10 \\
15 \\
10 \\
10\end{array}$ & $\begin{array}{l}0 \\
0 \\
0 \\
0 \\
0\end{array}$ & $\begin{array}{l}\text { nd } \\
\text { nd } \\
\text { nd } \\
\text { nd } \\
\text { nd }\end{array}$ & $\begin{array}{l}0 \\
0 \\
0 \\
0 \\
0\end{array}$ & $\begin{array}{l}\text { nd } \\
\text { nd } \\
\text { nd } \\
\text { nd } \\
\text { nd }\end{array}$ & $\begin{array}{c}0 \\
0 \\
46 \\
0 \\
0\end{array}$ & $\begin{array}{c}\text { nd } \\
\text { nd } \\
0.5 \pm 0.6 \\
\text { nd } \\
\text { nd }\end{array}$ & $\begin{array}{c}30 \\
20 \\
87 \\
80 \\
0\end{array}$ & $\begin{array}{c}0.5 \pm 0.8 \\
0.3 \pm 0.6 \\
2.5 \pm 2.2 \\
3.4 \pm 2.5 \\
\text { nd }\end{array}$ & $\begin{array}{c}30 \\
50 \\
50 \\
80 \\
0\end{array}$ & $\begin{array}{c}0.9 \pm 1.7 \\
0.8 \pm 1.0 \\
2.4 \pm 2.9 \\
3.4 \pm 3.8 \\
\text { nd }\end{array}$ \\
\hline
\end{tabular}

*nectar collected directly from rape flowers;

** nectar flow from combs; K2- the control group; nd - not detect

- red color indicates substances used as seed dressing or as a spray 
samples, no viruses were detected, except for a few samples in which the deformed wing virus (DWV) was found.

The mortality rate was checked during the whole beekeeping season. In 2010, since placing the colonies in the rape fields on the $30^{\text {th }}$ of April until the $21^{\text {st }}$ of July, no dead bees were found in any of the colonies. From the $21^{\text {st }}$ of July to the $18^{\text {th }}$ of October in group A, an average of 18 dead bees per colony was found; 20 in group B, and 14 in the control group. Therefore, the numbers of dead bees on the bottom boards and trays were very low and there were no significant differences between groups (Kruskal-Wallis test $\mathrm{H}=0.0787$; $\mathrm{p}=0.961$ ). During the time from the placing of the colonies on the rape fields until wintering, the colonies developed properly in all groups. Numbers of combs covered by bees and the brood areas assessed during each inspection proved that the colonies were in good condition, and that the colonies were typical for the time of season and did not differ significantly between groups (Tab. 9).
The development of the colonies after overwintering was assessed during the spring inspections conducted from April till May 2011. All colonies overwintered properly. The number of bees that had died during winter were examined on the $17^{\text {th }}$ of March 2011. The number was low and similar in all groups. In colonies from group A, 272 bees had died during the winter, 212 in group B and in the control group, 313 bees had died (Kruskal-Wallis test $\mathrm{H}=1.891 ; \mathrm{p}=0.388$ ).

In 2012, during the time when the colonies stayed in the rape fields, (from the $14^{\text {th }}$ of June) and after transporting them to the stationary apiary (until the $30^{\text {th }}$ of July) very low mortality was also noted. During this period, in groups C, $\mathrm{D}, \mathrm{E}$ and in the control group, an average of $4,7,11$, and 9 bees per colony died, respectively. Similarly to 2010 , all colonies were strong and developed properly during the beekeeping season (Tab. 10). In September, an assessment of bee colony condition was conducted. The assessment showed that the number of combs covered by bees and brood area in colonies foraging

Table 8 .

Incidence of other pesticides and level of their concentration $(\mathrm{ng} / \mathrm{g})$ in analyzed samples collected by bees from spring oilseed rape (2012)

\begin{tabular}{|c|c|c|c|c|c|c|c|c|}
\hline \multirow[t]{2}{*}{ active substance } & \multicolumn{4}{|c|}{$\begin{array}{c}\text { Samples of nectar } \\
\text { ( } \sum \text { samples of nectar from flowers, } \\
\text { nectar flow and honey) } n=133\end{array}$} & \multicolumn{4}{|c|}{$\begin{array}{c}\text { Samples of pollen } \\
\left(\sum \text { samples of pollen loads }\right. \\
\text { and bee bread }) n=115\end{array}$} \\
\hline & $\begin{array}{l}\text { Number } \\
\text { of positive }\end{array}$ & mean & $\max$ & median & $\begin{array}{l}\text { Number } \\
\text { of positive }\end{array}$ & mean & $\max$ & median \\
\hline Azoxystrobin (SF)* & 2 & 11.3 & 17.8 & 11.3 & nd & - & - & - \\
\hline Boscalid (SF)* & 4 & 40.5 & 73.1 & 38.1 & nd & - & - & - \\
\hline Carbendazim $(\mathrm{SF})^{\star}$ & 66 & 8.5 & 87.5 & 2 & 26 & 2.5 & 11.8 & 1.7 \\
\hline Cyproconazole(SF) $^{\star}$ & 3 & 6.1 & 8.3 & 8.1 & nd & - & - & - \\
\hline Desmedipham $(\mathrm{H})^{*}$ & 7 & 72.9 & 283.7 & 42.4 & nd & - & - & - \\
\hline Dimethoate $(\mathrm{SI})^{\star}$ & 24 & 1.7 & 5.9 & 1.2 & 22 & 1.6 & 7.0 & 1.3 \\
\hline Lenacil $(\mathrm{H})^{\star}$ & 33 & 143.0 & 2858.0 & 2 & 12 & 1.7 & 3.4 & 1.4 \\
\hline Metalaxil/Metalaxil-M (SF)* & 37 & 1.6 & 4.4 & 1.2 & nd & - & - & - \\
\hline Methoxyfenozide (GR) ${ }^{*}$ & 2 & 7.6 & 13.4 & 7.6 & nd & - & - & - \\
\hline Pendimethalin $(\mathrm{H})^{\star}$ & 13 & 4.2 & 12.1 & 3.2 & nd & - & - & - \\
\hline Phenmedipham $(\mathrm{H})^{\star}$ & 7 & 73.5 & 287.6 & 44.2 & nd & - & - & - \\
\hline Spiroxamine $(\mathrm{F})^{*}$ & 35 & 2.4 & 4.1 & 2.1 & 2 & 1.6 & 2.1 & 1.6 \\
\hline Thiophanate-methyl(SF)* & 27 & 128.0 & 1795.0 & 11.6 & nd & - & - & - \\
\hline Tebuconazole $(\mathrm{SF})^{\star}$ & 24 & 49.0 & 389.3 & 8.7 & nd & - & - & - \\
\hline
\end{tabular}

*I-insecticide, F- fungicide, H-herbicide, S-systemic, GR-growth regulator; nd - not detect 
on rape, and the control group, was similar. In both years, during the period of being placed in the oilseed rape fields as well as after being moved to the stationary apiary, none of the groups showed disturbances in development or functioning.

1.2.2 The rape honey and pollen harvest

Weather conditions during the May 2010 study period were atypical for this time of year. Heavy and continual rains lasting for almost the whole winter rape flowering period considerably limited bee flights, making good exploitation of the flow impossible. In May 2010, the rape honey yields from colonies in field $\mathrm{A}$ and field B were extremely low and amounted to 4.9 and $5.5 \mathrm{~kg}$ per colony, respectively. Approximately $2.0 \mathrm{~kg}$ of honey per colony was harvested in the control group. During that period, each colony, on average, collected from field A $880 \mathrm{~g}( \pm 580.4)$ of pollen and from field B $880 \mathrm{~g}( \pm 510.6)$. The average area of bee bread produced during 3 weeks on the winter oilseed rape fields did not exceed $5 \mathrm{dm}^{2}$ in both groups. The average content of Brassica napus pollen in the loads of pollen collected from field $\mathrm{A}$ was $92 \%$, while from field B only $6 \%$. In the latter samples, pollen of Prunus type Malus type, Rubus type, Salix, and Pinus predominated. The content of rape pollen in the bee bread, nectar and honey was similar from both crops and ranged from 25 to $53 \%$ (Tab. 3). In samples from the control group, pollen of Prunus type, Malus type, Rubus type, Asteraceae and Brassicaceae predominated, but pollen of Brassica napus was present as well.

On all the fields, during the 2012 spring rape blooming period, bee colonies collected considerably higher quantities

Table 9 .

Population size of honeybee colonies (2010)

\begin{tabular}{|c|c|c|c|c|c|c|c|c|}
\hline \multirow{2}{*}{$\begin{array}{l}\text { Date of } \\
\text { measure- } \\
\text { ment }\end{array}$} & \multicolumn{3}{|c|}{$\begin{array}{l}\text { Number of combs covered } \\
\text { by bees (mean } \pm \text { sd) }\end{array}$} & \multirow{2}{*}{$p$-value* } & \multicolumn{3}{|c|}{$\begin{array}{l}\text { Brood area }\left(\mathrm{dm}^{2}\right) \\
(\text { mean } \pm \mathrm{sd})\end{array}$} & \multirow{2}{*}{$p$-value* } \\
\hline & Group A & Group B & $\begin{array}{c}\text { The control } \\
\text { group }\end{array}$ & & Group A & Group B & $\begin{array}{l}\text { The control } \\
\text { group }\end{array}$ & \\
\hline 28.04 .10 & $14.4 \pm 1.6$ & $14.1 \pm 1.0$ & $14.3 \pm 1.1$ & 0.859 & $69.4 \pm 15.0$ & $65.7 \pm 11.5$ & $63.8 \pm 18.0$ & 0.703 \\
\hline 31.05 .10 & $19.7 \pm 0.7$ & $19.8 \pm 0.6$ & $19.1 \pm 1.2$ & 0.172 & $70.1 \pm 14.9$ & $77.2 \pm 8.6$ & $65.8 \pm 12.2$ & 0.162 \\
\hline 21.06 .10 & $20.0 \pm 0.0$ & $19.8 \pm 0.6$ & $19.4 \pm 1.0$ & 0.142 & $71.8 \pm 8.6$ & $77.1 \pm 10.1$ & $66.5 \pm 10.1$ & 0.105 \\
\hline 12.07 .10 & $20.0 \pm 0.0$ & $19.8 \pm 0.6$ & $19.4 \pm 1.0$ & 0.142 & $60.9 \pm 9.1$ & $60.2 \pm 20.3$ & $57.2 \pm 13.3$ & 0.865 \\
\hline 27.07 .10 & $9.0 \pm 0.0$ & $9.0 \pm 0.0$ & $9.0 \pm 0.0$ & & $50.4 \pm 8.1$ & $52.1 \pm 11.3$ & $44.6 \pm 10.1$ & 0.229 \\
\hline 24.08 .10 & $9.0 \pm 0.0$ & $9.0 \pm 0.0$ & $9.0 \pm 0.0$ & & $36.1 \pm 6.0$ & $33.8 \pm 5.3$ & $32.3 \pm 11.1$ & 0.556 \\
\hline 21.09 .10 & $9.0 \pm 0.0$ & $9.0 \pm 0.0$ & $9.0 \pm 0.0$ & & $10.3 \pm 7.0$ & $8.9 \pm 4.2$ & $9.3 \pm 5.0$ & 0.840 \\
\hline 18.10 .10 & $7.6 \pm 0.5$ & $7.3 \pm 0.7$ & $7.7 \pm 0.9$ & 0.477 & $2.2 \pm 0.7$ & $1.9 \pm 0.4$ & $2.1 \pm 1.5$ & 0.813 \\
\hline
\end{tabular}

*ANOVA test.

Table 10 .

Population size of honeybee colonies (2012)

\begin{tabular}{|c|c|c|c|c|c|c|c|c|c|c|}
\hline \multirow{2}{*}{$\begin{array}{c}\text { Date of } \\
\text { measure- } \\
\text { ment }\end{array}$} & \multicolumn{4}{|c|}{$\begin{array}{c}\text { Number of combs covered } \\
\text { by bees (mean } \pm \text { sd) }\end{array}$} & \multirow{2}{*}{$\begin{array}{l}\frac{\text { * }}{2} \\
\frac{1}{\pi} \\
\frac{1}{1} \\
2\end{array}$} & \multicolumn{4}{|c|}{$\begin{array}{l}\text { Brood area }\left(\mathrm{dm}^{2}\right) \\
(\text { mean } \pm \mathrm{sd})\end{array}$} & \multirow{2}{*}{ 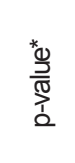 } \\
\hline & Group C & Group D & Group E & $\begin{array}{l}\text { The } \\
\text { control } \\
\text { group }\end{array}$ & & Group C & Group D & Group E & $\begin{array}{l}\text { The control } \\
\text { group }\end{array}$ & \\
\hline 14.06 .12 & $11.8 \pm 0.6$ & $12.0 \pm 0.0$ & $12.0 \pm 0.0$ & $11.6 \pm 0.8$ & 0.424 & $65.9 a b \pm 25.0$ & 59.0ab \pm 24.6 & $70.8 b \pm 10.9$ & $39.1 \mathrm{a} \pm 19.7$ & 0.03 \\
\hline 16.07 .12 & $12.0 \pm 0.0$ & $12.0 \pm 0.0$ & $12.0 \pm 0.0$ & $12.0 \pm 0.0$ & & $55.3 \pm 24.2$ & $54.8 \pm 7.2$ & $60.2 \pm 9.4$ & $46.8 \pm 14.3$ & 0.420 \\
\hline 01.08 .12 & $12.0 \pm 0.0$ & $12.0 \pm 0.0$ & $12.0 \pm 0.0$ & $11.7 \pm 0.8$ & 0.171 & $53.9 \pm 17.1$ & $55.6 \pm 12.5$ & $52.5 \pm 14.5$ & $49.4 \pm 12.1$ & 0.863 \\
\hline 20.08 .12 & $7.9 a \pm 0.6$ & $8.4 a \pm 0.5$ & $10.0 \mathrm{~b} \pm 0.0$ & $8.5 \mathrm{a} \pm 0.5$ & $<0.000$ & $46.1 \pm 10.0$ & $51.7 \pm 14.2$ & $48.5 \pm 8.1$ & $54.1 \pm 3.3$ & 0.433 \\
\hline 11.09 .12 & $5.8 \pm 0.4$ & $6.1 \pm 0.3$ & $5.9 \pm 0.3$ & $5.8 \pm 0.4$ & 0.290 & $2.2 \pm 2.2$ & $5.1 \pm 4.6$ & $3.6 \pm 3.8$ & $7.3 \pm 3.6$ & 0.058 \\
\hline 27.09 .12 & $5.8 \pm 0.4$ & $6.1 \pm 0.3$ & $5.9 \pm 0.3$ & $5.8 \pm 0.4$ & 0.290 & $3.2 \pm 2.3$ & $2.7 \pm 2.1$ & $2.7 \pm 2.5$ & $2.2 \pm 1.6$ & 0.838 \\
\hline
\end{tabular}

*ANOVA test. The different letters $(\mathrm{a}, \mathrm{b})$ indicate significant differences between the means 
of nectar and pollen than was collected from winter rape in 2010. The average rape honey yields from colonies in field C, D, and E amounted to $14.3 ; 16.8$, and $11.8 \mathrm{~kg} /$ colony, respectively. The honey yields from colonies in treated fields were not significantly different from those in control fields (Kruskal-Wallis test $\mathrm{H}=6.009 ; \mathrm{p}=0.106)$. The lowest average amount per colony was collected from field $\mathrm{E}(923 \mathrm{~g} \pm 214.4)$, while from fields $\mathrm{C}$ and $\mathrm{D}$, each colony collected approximately $1,400 \mathrm{~g}( \pm 365)$ of pollen loads. The surplus of pollen gathered as bee bread in combs by each colony during that time was, on average $18.6( \pm 6.4), 14.4$ $( \pm 6.0)$, and $15.3 \mathrm{dm}^{2}( \pm 4.3)$, respectively. The content of Brassica napus pollen in all the samples was high, indicating good exploitation of rape nectar and pollen flow (Tab. 3). The control group colonies were foraging mainly on Trifolium repens, Tilia, Fagopyrum, and Phacelia (Tab. 4).

\section{DISCUSSION}

1.1 The residues level of neonicotenoid insecticides applied as seed treatment and spraying

The highest contamination of nectar and pollen (expressed by the number of samples containing the substance and its residue level) was noted after the thiamethoxam seed treatment of rape (CRUISER OSR $322 \mathrm{FS}$ ). In $65 \%$ of the total nectar and honey samples and $37 \%$ of pollen loads and bee bread, on average, 4.2 and $3.8 \mathrm{ng} / \mathrm{g}$ of thiamethoxam was found. However, the concentration of thiamethoxam in the winter rape forage (in nectar and honey, on average, $1.6 \mathrm{ng} / \mathrm{g}$, in pollen $<\mathrm{LOD}$ ) was significantly lower in comparison to spring rape (in nectar and honey, on average, $8.7 \mathrm{ng} / \mathrm{g}$, in pollen $5.6 \mathrm{ng} / \mathrm{g}$ ). The reason for this difference could be the worse harvest of nectar and pollen flow from the winter oilseed rape crops. The average amounts of Brassica napus materials in the total mass of the examined samples collected from the winter rape was lower compared to the samples of spring rape. This presumption is based on the significant positive correlation between the percentage of Brassica napus grains and the level of thiamethoxam residues in respective samples.

These differences may have also been an effect of the longer period between dressing the winter rape seeds and rape florescence (over 6 months). During that time, partial decomposition of this substance could have occurred. Only 2 months had passed from dressing the seeds to the flowering of the spring oilseed rape. The impact of time can also be confirmed by the fact that no thiamethoxam was found in winter rape pollen samples, even those samples containing more than $90 \%$ of Brassica napus pollen. Thiamethoxam was present but in lower amounts in samples from spring rape fields whose seeds were not dressed at all (field D and E). The source of these thiamethoxam residues could be the nectar and pollen from the surrounding fields. It is supported by the fact that in the spring rape samples pollen grains of the following species and genres were present: Centaurea cyanus, Phacelia, Fagopyrum, Trifolium repens, Rubus type. Thiamethoxam was also found in nectar from rape flowers, hence, other sources of pesticide exposure cannot be ruled out e.g. the soil (Girolami et al., 2009; Tapparo et al., 2011; Krupke et al., 2012).

So far, thiamethoxam residues were rarely detected in bee collected plant materials. In the 3-year German bee monitoring project, residues of thiametoxam were not detected in any of the 215 bee bread samples collected from bee colonies after the oilseed rape blooming period (no data available on pesticide applied in crops) (Genersch etal., 2010). In North America, thiametoxam residue was found in only one $(53 \mathrm{ng} / \mathrm{g})$ of the 350 pollen samples collected from apiaries across 23 U.S. states and one Canadian province and several agricultural cropping systems (Mullin et al., 2010).

From the few results published so far, concerning thiamethoxam residues in plant materials collected by bees, and/or thiamethoxam residues in bee products, the results most similar to those presented here 
were obtained by Krupke et al. (2012). In their research thiamethoxam was detected in 7 of the 24 pollen samples originating from hives placed near maize and soybean crops treated with thiamethoxam and clothianidin. The thiamethoxam contamination ranged between 1.2 and $7.4 \mathrm{ng} / \mathrm{g}$ in 20 samples of pollen loads but was higher in bee bread collected from four hives. In 2 samples from 2 healthy colonies, the average was $6.2 \mathrm{ng} / \mathrm{g}$, and $20.4 \mathrm{ng} / \mathrm{g}$ from 2 sick colonies. Significantly higher amounts of thiamethoxam $(11.9 \mathrm{mg} / \mathrm{l})$ were detected in the guttation fluid from maize plants treated with CRUISER 350 FS (Girolami et al., 2009). In field conditions, the concentration of CRUISER $350 \mathrm{FS}$ was significantly higher and depended on soil moisture content. CRUISER 350 FS concentration was from 14-155 mg/1 for plants grown under wet conditions to 34-1,154 mg/l under dry conditions (Tapparo et al., 2011).

Clothianidin was recorded in $17 \%$ of the combined nectar and honey samples (the average content $2.3 \mathrm{ng} / \mathrm{g}$ ), and in $11 \%$ of pollen samples $(1.8 \mathrm{ng} / \mathrm{g})$. All samples containing clothianidin originated from spring oilseed rape treated with MODESTO 480 FS (a.s. $4.9 \mathrm{~g} / \mathrm{kg}$ seeds). A similar study was performed in Canada, on two experimental fields of spring oilseed rape (treated with PROSPER $8 \mathrm{FL}$ and PONCHO $600 \mathrm{FS}$ delivering clothianidin at $4.0 \mathrm{~g} / \mathrm{kg}$ seeds). The results differ somewhat from ours. The majority of Canadian samples $(>75 \%)$ had no detectable level of clothianidin residues and the maximum concentration of clothianidin detected in honey, nectar, and pollen samples were lower: $0.9 ; 2.2 ; 2.6 \mathrm{ng} / \mathrm{g}$, respectively (Cutler and Scott-Dupree, 2007). The clothianidin contamination of seed dressed oilseed rape in nectar of returning forager bees defined by Wallner (2004) was from 2 to $3 \mathrm{ng} / \mathrm{g}$.

In the broad German and North American survey of pesticide residues, no clothianidin was found in samples of stored pollen from hives (Geners ch et al., 2010; Mullin et al., 2010). In the EU member states insecticides containing clothianidin are used mainly as seed dressing, however preparations with imidacloprid and thiamethoxam are used three times more frequently (EFSA Journal, 2012). Therefore, it may be assumed that potential exposure of bees to clothianidin toxicity would be lower in comparison to other neonicotinoids.

The lowest contamination levels of plant materials and bee products were found by us after dressing the oilseed rape seeds with imidacloprid at a dose of $2.1 \mathrm{~g} / \mathrm{kg}$ seeds. Residues of imidacloprid were present in $21 \%$ of the total nectar and honey samples, on average below $1 \mathrm{ng} / \mathrm{g}$. No imidacloprid was detected in pollen samples, even in the samples with a high percentage of Brassica napus pollen grains. The results presented here are consistent with those of other studies, although the materials from the other studies were of a very diverse botanical origin. In general, the majority of the studies reported lower frequencies of imidacloprid presence in pollen and honey. In the nectar and pollen of the seedtreated sunflower field plants (GAUCHO WS 70 , dose a.s. $0.7 \mathrm{mg}$ per seed) neither imidacloprid nor its metabolites were found (Schmuck et al., 2001). In Spain, the analysis of pesticides residues (LOD $<0.4$ $\mu \mathrm{g} / \mathrm{kg}$ ) was conducted on 1,100 stored pollen samples, originating from different regions of the country and imidacloprid was not found in any of the samples (Bernal et al., 2010; Higes et al., 2010). In Germany, from the colonies exploiting oilseed rape flow, 215 bee bread samples were collected and the imidacloprid residues were only found in one sample (Geners ch et al., 2010). In North America (in spite of significant differences in field and gardening techniques), bee bread samples with imidacloprid amounted to $2.9 \%$ and, on average, contained $3.1 \mu \mathrm{g} / \mathrm{kg}$ (Mullin et al., 2010). Nguyen et al. (2009) noted imidacloprid in $8.4 \%$ of the honey samples from an area with $13.2 \%$ of the seeddressed maize crop, but levels of residues were below the limit of quantification $(0.5 \mu \mathrm{g} / \mathrm{kg})$. Residues of imidacloprid 
and its metabolite 6-chloronicotinic acid were detected the most frequently in pollen loads, honey, and the honey bees themselves, by Chauzat et al. (2006, 2009, 2011). Imidacloprid was found in $40.5 \%$ (an average of $2.1 \mu \mathrm{g} / \mathrm{kg}$ ) of the trapped pollen and $21.8 \%$ of the honey samples.

Spraying the rape fields with acetamiprid or thiacloprid preparations resulted in nectar, honey, and pollen contamination in every case, however, the concentration of these substances was low in the majority of samples. After spraying with acetamiprid a week before placing the bee colonies on the rape field, the nectar and pollen contamination was significantly higher than acetamiprid content in the flow collected after two weeks from the spraying. Thus, it is possible that a substantial amount of acetamiprid could have undergone decomposition during this time. The level of thiacloprid residues was highly variable despite the fact that all fields were sprayed at the same time. In nectar samples, thiacloprid content ranged from 1 to $208.8 \mathrm{ng} / \mathrm{g}$, and in pollen samples from 2.0 to $369.0 \mathrm{ng} / \mathrm{g}$. These results may be due to irregular application of insecticides on sprayed plants, causing different levels of contamination of pollen and nectar flow.

In addition, residues of acetamiprid and/or thiacloprid were found in samples from the remaining rape fields and in the control colonies. Especially high levels of thiacloprid residues (average $646 \mathrm{ng} / \mathrm{g}$, max. $1002.2 \mathrm{ng} / \mathrm{g}$ ) were found in pollen loads in which pollen of orchard plants (Prunus type, Malus type, Rubus type) predominated (the control group K1). This proves that these neonicotinoids are widely used to protect other crops which are a source of nectar or pollen for bees as well. Acetamiprid was present in almost half of all studied nectar and pollen samples, thiacloprid in over $60 \%$. This confirms that preparations applied as sprays are of a greater danger for pollinating insects. Frequent occurrence of thiacloprid in the pollen stored in combs (33\% of thiacloprid positive samples) was also shown during pesticide monitoring in German apiaries.
However, acetamiprid was only found in 2 out of 215 samples (Genersch et al., 2010). In similar research conducted in North America, very low numbers of both substances were found in pollen samples; thiacloprid in $5.4 \%$, acetamiprid in $3.1 \%$ (Mullin et al., 2010).

In our study, the insecticides used in the seed treatments were detected significantly more frequently in nectar and honey samples than in pollen loads and bee bread samples (chi-square test, $\mathrm{p}<0.0000$ ). The levels of the insecticide residues were also significantly higher. This interrelation was not proven in the analysis of insecticide residues from spraying (chi-square test, $\mathrm{p}=0.2802$ ). Thus, it can be assumed that nectar or honey samples are a better matrix for analyzing systemic, hydrophilic insecticide residues used as seed dressing.

1.2 Short- and long-term effect of neonicotinoid residues on bee colonies

It can be concluded, that honey bees foraging on seed-treated and sprayed oilseed rape are exposed to clothianidin, imidacloprid, thiamethoxam, acetamiprid and thiacloprid residues in pollen, nectar, and honey. In assessing the exposure of bees, the amounts of contaminated nectar, honey, and pollen consumed by various bee castes were taken into account (Rortais et al., 2005). Knowing the insecticide residues in rape nectar and pollen we have calculated the daily consumption of bees, and the daily uptake of these compounds. Even though the identified by us concentrations of insecticides were varied, they were below the concentrations which induce acute lethal effects, as the substances differ in their toxicity for honey bees. The acute oral and contact toxicity $\left(\mathrm{LD}_{50}\right)$ values of clothianidin were defined at $3 \mathrm{ng} / \mathrm{bee}$ and 22-44 $\mathrm{ng} / \mathrm{bee}$, respectively. The lethal effect of imidacloprid was observed at $3.7 \mathrm{ng} /$ bee for oral toxicity and at 14-24 ng/bee for contact toxicity. For thiamethoxam, the $\mathrm{LD}_{50}$ values are 4-5 ng/bee, and 24-30 ng/bee, respectively. The $\mathrm{LD}_{50}$ concentrations of acetamiprid and thiacloprid are higher and amount to $14.5 \mu \mathrm{g} /$ bee (oral), $8.09 \mu \mathrm{g} /$ bee (contact), 
and $17.2 \mu \mathrm{g} /$ bee (oral), and $38.82 \mu \mathrm{g} /$ bee (contact), respectively for these compounds (Iwsa et al., 2004; Decourtye and Devillers, 2010; Laurino et al., 2011).

The highest levels of residues were noted by us after the thiamethoxam seed treatment. The overall thiamethoxam residue intake was calculated to be between $0.4-3.3 \mathrm{ng} / \mathrm{bee} /$ day for a forager and between $0.4-1.4 \mathrm{ng} / \mathrm{bee} /$ day for a nurse bee. In the study of Henry et al. (2012) sublethal effects on the return flight ability of bees were observed at $1.34 \mathrm{ng} / \mathrm{bee}$. Oral uptake of $3.0 \mathrm{ng} /$ bee of thiamethoxam resulted in memory impairments of foragers (Decourtye and Devillers, 2010).

We observed no adverse effect of detected residues on survival and overall colony health. The assessment of the health status of bee colonies during the flowering period and after their displacement to the stationary apiary showed no significant differences between those treated, the control and other bee colonies. None of the bees from any of the oilseed rape fields showed symptoms of lethal toxic effects of pesticide residues nor was there an increase in bee mortality. Bee colony population size and bee development were normal and appropriate for the time of the season in which the assessment took place. There was no statistical difference in the amount of capped and uncapped brood area or in the number of combs covered by bees. The assessment of overwintered colonies in spring 2011, found no chronic effect on their status. All bee colonies survived the 2010/2011 winter period, and bee strength and development were correct.

The study of the sublethal effects of the residues on the physiology and behavior of an individual (learning ability, olfactory memory, orientation, foraging activity) requires other methods e.g. proboscis extension reflex (PER) conditioning, (Decourtye et al., 2005) or radiofrequency identification (RFID) (Schneider et al., 2012; Henry et al., 2012). We did not use these methods in our research, however, chronic exposure to sublethal doses shown by impairment of food collection and/or reproduction may also be the cause of the weakness of bee colonies. During the whole observation period, no abnormalities in colony development occurred. Thus, we can suppose that the residue levels determined in nectar and pollen did not have a sublethal effect on bees nor that the effect of the residue levels was relevant to the proper development and functioning of the bee colonies. Wallner and Engl (2004), Bailey et al. (2005), and Cutler and Scott-Dupree (2007) also did not observe any side-effects on the bee colonies from oilseed rape treated with clothianidin and imidacloprid.

Nevertheless, it has been proven that nectar and pollen of intensively protected commercial oilseed rape fields contains more neonicotinoid insecticide residues in comparison to other crops Over $50 \%$ of the examined samples were contaminated with 2 neonicotinoid substances simultaneously, and in over $25 \%$ of the samples, at least 3 substances were found. This was ascertained also by Genersch et al. (2010). The nectar collected by bees is converted into honey and extracted by beekeepers within a short time so bees actually use a small amount of this forage. This is why pollen stored in combs causes a greater toxicological threat. However, a certain amount of the honey is also stored in the brood nest. The sideeffect of neonicotinoids on the honeybee colony may depend on the amount of food collected.

The results show that the residues of pesticides determined by us have not impaired the healthy honeybee colonies. However, the risk exposure of bee colonies to the adverse impacts of pesticide residues is high in areas of intensive oilseed rape cultivation. It needs to be remarked that the toxic effects of neonicotinoids may be related to the physiological and health state of bees/colonies. A significant increase in honey bee mortality was observed in laboratory condition, when $N$. ceranaeinfected honey bees were exposed to sublethal doses of fipronil and thiacloprid. Mortality of infected only bees was $47 \%$ 
compared to $82 \%$ and $71 \%$ for infected bees exposed to fipronil and thiacloprid, respectively. Mortality of bees exposed to only thiacloprid or fipronil was not different from the control group (Vidau et al., 2011). In laboratory study conducted by Au fauvre et al. (2012) N. ceranae-fipronil combination led to a significant decrease in honey bee survival compared to either the control or single treatments. The interaction between the Nosema and imidacloprid also significantly weakened honeybees (Alaux et al., 2010). These interactions and/or the synergistic effect of mixtures containing compounds from various chemical groups (Iwsa et al., 2004) may cause the levels of residues detected in rape nectar and pollen to prove hazardous for honeybees infected/infested with pathogens/ parasites. In addition, interactions between insecticides and pathogens/parasites have, so far, only been known to a small extent. To fully assess the toxicological effect of neonicotinoid residues on bees, further research is necessary.

\section{CONCLUSIONS}

1. Neonicotinoid insecticides (imidacloprid, thiamethoxam, clothianidin acetamiprid and thiacloprid,) applied as seed treatment and used to spray oilseed rape fields resulted in contamination of nectar and pollen bee forage. The highest levels of residues were noted after the thiamethoxam seed treatment.

2. The average concentrations of these compounds in nectar and pollen samples were lower than the oral and contact toxicity $\mathrm{LD}_{50}$ values.

3 . The contaminations of neonicotinoids applied as seed dressings in nectar samples were significantly higher in comparison to the contaminations of neonicotinoids in pollen samples.

4. The most prevalent insecticides in pollen and nectar collected by honeybees were thiamethoxam, thiacloprid, and acetamiprid.

5. Short- and long-term side effects of the applied seed treatment and spraying of winter and spring oilseed rape on development and productivity of healthy bee colonies were not observed.

6 . The risk exposure of bee colonies to the adverse impacts of pesticide residues is high in areas of intensive oilseed rape cultivation.

\section{ACKNOWLEDGMENTS}

This study was supported by the Ministry of Science and Higher Education, COST ACTION FA0803, grant number $527 / \mathrm{N}-\mathrm{COST} / 2009 / 0$.

We thank Mr. Leszek Telec, Director Agricultural Experimental Unit of Institute of Soil Science and Plant Cultivation, for help in conducting of field study.

\section{REFERENCES}

Alaux C., Brunet J. L., Dussaubat C., Mondet F., Tchamitchan S., Cousin M., Brillard J., Baldy A., Belzunces L. P., LeConte Y. (2010) - Interactions between Nosema microspores and a neonicotinoid weaken honeybees (Apis mellifera). Environ. Microbiol., 12: 774-782. $\begin{array}{ccc}\text { Aliouane Y., } & \text { Adessalam } & \text { K., } \\ \text { El Hassani } & \text { A.K., Gary } & \text { V., } \\ \text { Armengaud } & \text { C.,Lambin } & \text { M., } \\ \text { Gauthier M (2009) - Subchronic exposure }\end{array}$ of honeybees to sublethal doses of pesticides: effect on behavior. Environ. Toxicol. Chem., 28: 113-122.

Anastassiades M., Lehotay S. (2003) - Fast and easy multiresidue method employing acetonitrile extraction/partitioning and "Dispersive Solid-Extraction" for the determination of pesticide residue in produce. J. AOAC Int., 86: 412-431.

Aufauvre J., Biron D. G., Vidau C., Fontbonne R., Roudel M., Diogon M., Vigues B., Belzunces L. P., Delbac F., Blot N. (2012) - Parasite-insecticide interactions: a case study of Nosema ceranae and fipronil synergy on honey bee. Sci. Rep., 2: 326 . 
Bailey J., Scott-Dupree C., Harris R., Tolman J., Harris B. (2005) - Contact and oral toxicity to honey bees (Apis mellifera) of agents registered for use for sweet corn insect control in Ontario, Canada. Apidologie, 36: 623-633.

Bernal J., Garrido-Bailon E., del Nozal M. J., Gonzalez-Porto A. V., Martin-Hernandez R., Diego J. C., Jimenez J. J., Bernal J. L., Higes M. (2010) - Overview of pesticide residues in stored pollen and their potential effect on bee colony (Apis mellifera) losses in Spain. J. Econ. Entomol., 103: 1964-1971.

Bortolotti L., Montanari R., Marcelino J., Medrzycki P., Maini S., Porrini C. (2003) - Effects of sub-lethal imidacloprid doses on the homing rate and foraging activity of honey bees. Bull. Insectol., 56: 63-67.

Chauzat M. P., Carpentier P., Martel A. C., Bougeard S., Cougoule N., Porta P., Lachaize J., Madec F., Aubert M., Faucon J. P. (2009) - Influence of pesticide residues on honey bee (Hymenoptera: Apidae) colony health in France. Environ. Entomol., 38: 514-523.

Chauzat M. P., Faucon J. P., Martel A. C., Lachaize J., Cougoule N., Aubert M. (2006) - A survey of pesticide residues in pollen loads collected by honey bees in France. J. Econ. Entomol., 99: 253-262.

Chauzat M. P., Martel A. C., Cougoule N., Porta P., Lachaize J., Zeggane S., Aubert M., Carpentier P., Faucon J. P. (2011) - An assessment of honeybee colony matrices, Apis mellifera (Hymenoptera Apidae) to monitor pesticide presences in continental France. Environ. Toxicol. Chem., 30: 103-111.

Cutler G. C., Scott-Dupree C. D. (2007) Exposure to clothianidin seed-treated canola has no long-term impact on honey bees. J. Econ. Entomol., 100: 765-772.
Decourtye A., Armengaud C., Renou M., Devillers J., Cluzeau S.,Gauthier M., PhamDelègue M. H. (2004b) - Imidacloprid impairs memory and brain metabolism in the honeybee (Apis mellifera L.). Pest. Biochem. Physiol., 78: 83-92.

Decourtye A., Devillers J. (2010) Ecotoxicity of neonicotinoid insecticides to bees, in: Thany SH (Ed.) Insect nicotinic acetylcholine receptors, $1^{\text {st }}$ edn. Springer, New York, pp. 85-95.

Decourtye A., Devillers J., Cluzeau S., Charreton M., Pham-Delègue M. H. (2004a) - Effects of imidacloprid and deltamethrin on associative learning in honeybees under semifield and laboratory conditions. Ecotoxicol. Environ. Saf., 57: 410-419.

Decourtye A., Devillers J., Genecque E., Le Menach K., Budzinski H., Cluzeau S., Pham Delègue M. H (2005) - Comparative sublethal toxicity of nine pesticides on olfactory learning performances of the honeybee Apis mellifera. Arch. Environ. Contam. Toxicol., 48: 242-250.

Decourtye A., Le Metayer M., Pottiau H., Tisseur M., Odoux J. F., Pham-Delègue M. H. (2001) - Impairment of olfactory learning performances in the honey bee after long term ingestion of imidacloprid. In Proceedings of the $7^{\text {th }}$ International Symposium "Hazards of pesticides to bees",September 7-9, 1999, Avignon, France., 98: 113-117.

Desneux N., Decourtye A., Delpuech J. M. (2007) - The sublethal effects of pesticides on beneficial arthropods. Annu. Rev. Entomol., 52: 81-106.

European Food Safety Authority (2012) - Statement on the findings in recent studies investigating sub-lethal effects in bees of some neonicotinoids in consideration of the uses currently authorised in Europe. EFSA Journal, 10(6): 2752.

Genersch E., von der Ohe W., Kaatz H., Schroeder A., Otten C. (2010) - The German bee monitoring project: a long term study to understand periodically high winter losses of honey bee colonies. Apidologie, 41: 332-352. 
Girolami V., Mazzon L., Squartini A., Mori N., Marzaro M., Di Bernardo A., Greatti M., Giorio C., Tapparo A. (2009) - Translocation of neonicotinoid insecticides from coated seeds to seedling guttation drops: a novel way of intoxication for bees. J. Econ. Entomol., 102: 1808-1815.

Henry M., Beguin M., Requier F., Rollin O., Odoux J. F., Aupinel P., Aptel J., Tchamitchian S., Decourtye A. (2012) - A common pesticide decreases for-aging success and survival in honey bees. Science, 336(6079): 348-350. DOI: $10.1126 /$ science. 1215039 .

Higes M., Martin-Hernandez R., Martinez-Salvador A., GarridoBailon E., Gonzalez-Porto A. V., Meana A., Bernal J. L., del Nozal M. J., Bernal J. (2010) - A preliminary study of the epidemiological factors related to honey bee colony loss in Spain. Environ. Microbiol Rep., 2: 243-250.

Iwasa T., Motoyama N., Ambrose J. T. Roe M. R. (2004) - Mechanism for the differential toxicity of neonicotinoid insecticides in the honey bee, Apis mellifera. Crop Prot., 23: 371-378.

Jabłoński B. (2002) - Notes on the method to investigate nectar secretion rate in flowers. J. Apic. Sci., 46(2): 117-125.

Johnson R. M., Ellis M. D., Mullin C. A., Frazier M. (2010) Pesticides and honey bee toxicity - U.S.A., Apidologie, 41(3): 312-331.

Kołtowski Z. (2007) - Degree of utilization of potential sugar yield of a rapeseed plantation by insects inrespect of rapeseed honey yield in an apiary. J. Apic. Sci., 51(2): 67-79.

Krupke C. H., Hunt G. J., Eitzer B. D., Andino G., Given K. (2012) - Multiple routes of pesticide exposure for honey bees living near agricultural fields. PLOS ONE, 7(1): e29268. DOI:10.1371/journal.pone.0029268.

Laurino D., Porporato M, Patetta A., Manino A. (2011) - Toxicity of neonicotinoid insecticides to honey bees laboratory tests. Bull. Insectol., 64: 107-113.
Louveaux J., Maurizio A., Vorwohl G. (1978) - Methods of Melissopalynology. Bee World, 59(4): 139-157.

Mullin C. A., Frazier M., Frazier J. L., Ashcraft S., Simonds R. (2010) - High levels of miticides and agrochemicals in North American apiaries: implications for honey bee health. PLOS ONE, 5(3): e9754. DOI: 10.1371 /journal.pone.0009754.

Nguyen B. K., Saegerman C., Pirard C., Mignon J., Widart J., Tuirionet B., Verheggen F. J., Berkvens D., De Pauw E., Haubruge E. (2009) Does imidacloprid seed-treated maize have an impact on honey bee mortality? J. Econ. Entomol., 102: 616-623.

Pohorecka K., Bober A., Skubida M., Zdańska D. (2011) - Epizootic status of apiaries with massive losses of bee colonies (2008-2009). J. Apic. Sci., 55(1): 137-150.

Rortaisa A., Arnolda G., Halmb M. P., Touffet-Briensb F. (2005) - Modes of honeybees exposure to systemic insecticides: estimated amounts of contaminated pollen and nectar consumed by different categories of bees. Apidologie, 36(1): 71-83.

Schneider C. W., Tautz J., Grünewald B., Fuchs S. (2012) RFID Tracking of sublethal effects of two neonicotinoid insecticides on the foraging behavior of Apis mellifera. PLOS ONE, 7(1): e30023. DOI:10.1371/journal.pone.0030023.

Schmuck R., Schöning R., Stork A., Schramel O. (2001) - Risk posed to honeybees (Apis mellifera L., Hymenoptera) by an imidacloprid seed dressing of sunflowers. Pest Manag. Sci., 57: 225-238.

Tapparo A., Giorio C., Marzaro M., Marton D., Solda' L., Girolami V. (2011) - Rapid analysis of neonicotinoid insecticides in guttation drops of corn seedlings obtained from coated seeds. J. Environ. Monit., 13: $1564-1568$.

Thompson H. M., Maus C. (2007) - The relevance of sublethal effects in honey bee testing for pesticide risk assessment. Pest. Manag. Sci., 63: 1058-1061. 
Vidau C., Diogon M., Aufauvre J., Wiest L., Bulete A., Giroud B., Fontbonne R., Vigue`s B., Brunet J. L., Fratta C., Amic S., Lambert O., Texier C., Biron D. G., Blot N., Poliquen H., Arnaudguilhem C. (2011) Alaoui H. E., Belzunces L. P., Delbac F. - Multi-residue analysis of 80 environmental (2011) - Exposure to sublethal doses of fipronil contaminants in honeys, honeybees and pollens and thiacloprid highly increases mortality of by one extraction procedure followed by liquid honeybees previously infected by Nosema and gas chromatography coupled with mass ceranae. PLOS ONE, 6: e21550.

Wallner K., Eng1 M. (2004) - Observations on bee colonies at rape seed fields, seed dressed with different products. In Proceddings of Bees and Pesticides Symposium, First European Conference of Apidology, Udine 19-23, September 2004: 122-123. spectrometric detection. J. Chromatogr. A, 1218: 5743-5756.

Yang E. C., Chuang Y. C., Chen Y. L., Chang L. H. (2008) - Abnormal foraging behaviour induced by sublethal dosage of imidacloprid in the honey bee (Hymenoptera: Apidae). J. Econ. Entomol., 101: 1743-1748.

\title{
POZOSTALOŚCI INSEKTYCYDÓW NEONIKOTYNOIDOWYCH W NEKTARZE I PYLKU ZBIERANYM PRZEZ PSZCZOLY Z UPRAW RZEPAKU I ICH WPLYW NA RODZINY PSZCZELE
}

\author{
Pohorecka K., Skubida P., Miszczak A., \\ Semkiw P., Sikorski P., Zagibajło K., Teper D., \\ Koltowski Z., Skubida M., Zdańska D., Bober A.
}

S t r e s z c z e n i e

Celem badań była ocena narażenia rodzin pszczelich na toksyczne oddziaływanie pozostałości systemicznych insektycydów neonikotynoidowych zastosowanych w warunkach polowych do chemicznej ochrony upraw rzepaku.

Badania polowe przeprowadzone zostały przy współpracy z Rolniczym Zakładem Doświadczalnym Instytutu Uprawy, Nawożenia i Gleboznawstwa w Puławach na 2 plantacjach rzepaku ozimego w roku 2010 i 3 plantacjach rzepaku jarego w roku 2012. Do zwalczania szkodników zastosowano $\mathrm{w}$ formie zapraw nasiennych preparaty zawierające tiametoksam, chlotianidynę lub imidachlopryd oraz $\mathrm{w}$ formie oprysku dolistnego, preparaty z acetamiprydem lub tiachloprydem. Na wszystkich uprawach wykonane zostały także zabiegi chwastobójcze i grzybobójcze. Na okres kwitnienia roślin rzepaku, w pobliżu każdej plantacji umieszczono 15 rodzin pszczelich, z czego 5 rodzin w każdej grupie przeznaczonych było jedynie do pozyskiwania obnóży pyłkowych. Grupę kontrolną stanowiły rodziny usytuowane w terenie rolniczym wolnym od dużych upraw rzepaku. Od chwili wywiezienia rodzin pszczelich na rzepak, aż do okresu ich zazimowania (w roku 2012 do września) monitorowano śmiertelność pszczół oraz cyklicznie oceniano parametry świadczące o kondycji i rozwoju rodzin (liczbę ramek obsiadanych przez pszczoły oraz powierzchnię czerwiu krytego i otwartego). Do badań laboratoryjnych pobrano próbki nektaru z kwiatów rzepaku, próbki nektaru, miodu i pyłku (obnóży pyłkowych i pierzgi) zgromadzonego przez pszczoły w plastrach oraz próbki pszczół. Pochodzenie botaniczne próbek materiału roślinnego określono na podstawie analizy palinologicznej. Analizę pozostałości insektycydów w zebranym materiale wykonano metodą QuEChERS z wykorzystaniem chromatografu cieczowego sprzężonego z podwójnym detektorem masowym (LC-MS/MS). 
W badanych próbkach nektaru i pyłku wykryto pozostałości wszystkich substancji neonikotynoidowych aplikowanych zarówno w formie zapraw nasiennych, jak i oprysku. Znacząca liczba próbek zanieczyszczona była dodatkowo substancjami, których nie stosowano w czasie zabiegów. Największa liczba próbek skażona była tiametoksamem, tiachloprydem i acetamiprydem. Obecność tych substancji wykryto odpowiednio w 65, 64 i 51\% ogółem przebadanych próbek nektaru i miodu oraz w 37, 62 i 45\% próbek pyłku. We wszystkich rodzajach próbek stężenie neonikotynoidów było niższe od ich doustnej i kontaktowej dawki letalnej $\left(\mathrm{LD}_{50}\right)$ dla pszczół, ale w ponad $50 \%$ próbek obecne były co najmniej 2 substancje $\mathrm{z}$ tej grupy, a w ponad $25 \%$ co najmniej 3. Najwyższy poziom skażenia nektaru i pyłku odnotowano w przypadku zaprawiania nasion rzepaku jarego preparatem insektycydowym zawierającym tiametoksam. Insektycydy stosowane w formie zapraw nasiennych powodowały istotnie wyższe skażenie nektaru i miodu niż pyłku. W próbkach nektaru i pyłku pochodzących z rzepaku ozimego stwierdzono niższy poziom pozostałości neonikotynoidów w porównaniu do próbek z rzepaku jarego. W okresie całego sezonu pszczelarskiego 2010 i 2012 roku nie stwierdzono zwiększonej śmiertelności pszczół ani zaburzeń w rozwoju, kondycji i produkcyjności rodzin pszczelich. Po okresie zimowania 2010/2011 kondycja i rozwój rodzin pszczelich były także prawidłowe.

Pozostałości insektycydów neonikotynoidowych znajdujące się w nektarze i pyłku zbieranym przez pszczoły z upraw rzepaku chronionego insektycydami neonikotynoidowymi stwarzają wysokie ryzyko ich toksycznego oddziaływania na rodziny pszczele, szczególnie dla rodzin osłabionych innymi czynnikami (np. obecnością patogenów, pasożytów), ze względu na możliwość wystapienia zjawiska interakcji i/lub synergizmu.

Słowa kluczowe: pszczoła miodna, rzepak, insektycydy neonikotynoidowe, zaprawianie nasion, opryski, analiza pozostałości, wpływ na rodziny pszczele. 